University of Nebraska - Lincoln

DigitalCommons@University of Nebraska - Lincoln

Faculty Publications, Classics and Religious

Studies Department

\title{
$5-2011$
}

\section{Buddhist Contributions to the Question of (Un)mediated Mystical Experience}

Yaroslav Komarovski

University of Nebraska-Lincoln, ykomarovski2@unl.edu

Follow this and additional works at: https://digitalcommons.unl.edu/classicsfacpub

Part of the Classics Commons

Komarovski, Yaroslav, "Buddhist Contributions to the Question of (Un)mediated Mystical Experience" (2011). Faculty Publications, Classics and Religious Studies Department. 118.

https://digitalcommons.unl.edu/classicsfacpub/118

This Article is brought to you for free and open access by the Classics and Religious Studies at DigitalCommons@University of Nebraska - Lincoln. It has been accepted for inclusion in Faculty Publications, Classics and Religious Studies Department by an authorized administrator of DigitalCommons@University of Nebraska - Lincoln. 


\title{
Buddhist Contributions to the Question of (Un)mediated Mystical Experience
}

\author{
Yaroslav Komarovski \\ Department of Classics \& Religious Studies, University of Nebraska-Lincoln, \\ 240 Andrews Hall, Lincoln, NE 68588-0337, USA \\ Email: ykomarovski@gmail.com or ykomarovski2@unlnotes.unl.edu
}

Keywords: mysticism, mystical experience, religion, religious experience, Buddhist philosophy, Tibetan Buddhism

In this article, I address divergent Buddhist positions on conceptual and non-conceptual understanding of reality and the process of transition from the former to the latter. My discussion is anchored in the context of a well-known problematic issue in the field of religious studies, namely, the question of (un)mediated mystical experience. Connecting uniquely Buddhist philosophical and contemplative perspectives with the questions debated in contemporary studies of mysticism, I argue that Buddhism can make significant contributions to that field. Not only does it provide refined models of mind, contemplative processes, and other elements that help us understand certain mystical experiences, but it also encourages us to rethink the very meaning of "mediation," "ineffability," "experience," and other categories used in discussions of mysticism. The application of the category of mystical experience to Buddhist traditions thereby problematizes that category itself, simultaneously suggesting new meanings and perspectives. Far from being passive objects of contemporary scholarly Euro-American discourse on this issue, Buddhist traditions can actively engage, challenge, and modify that discourse.

Research into specificities of experiences, insights, and realizations articulated by Buddhists themselves and interpreted from within the context of Buddhist worldviews and practices has much more to offer to the study of mysticism and mystical experiences than the one that starts with generalizations about mysticism across diverse religions grouped under such categories as "theistic," "non-theistic," and so forth. For example, most Buddhists would disagree that such key Buddhist experiences as realization of ultimate reality and awakening or "enlightenment" are accessible to those who have not undergone specific types of Bud-

\footnotetext{
1 Throughout this paper, I am using "awakening” instead of "enlightenment." See note 57 for details.
} 
dhist training and conditioning. At the same time, they also agree on similarities or sameness of certain experiences across Buddhist traditions. That consensus in its turn is often interwoven with fierce polemics against seeming flaws of Buddhist traditions disagreeing with one's own in the areas of contemplation, identification of reality, results of meditative practice, and so forth. Studying these elements across Buddhist traditions and analyzing how Buddhists themselves approach such differences, similarities, uniqueness, and diversity will greatly contribute to a more nuanced overall understanding of mysticism and mystical experiences.

In particular, I argue that if the category of "mystical experience" is applicable to Buddhism at all, the direct realization of ultimate reality (Skt. paramärthasatya) ${ }^{2}$ or emptiness (Skt. śünyatā) should be treated as one of the highest expressions of that experience in the Buddhist context because of its supreme soteriological value as the only direct antidote to impediments to awakening. Likewise, because that realization both transcends and destroys conceptuality, mundane mentality, and dualistic thinking, it best approximates the category of "unmediated mystical experience," if such a category has any relevant use in the Buddhist context. Correspondingly, because the process of direct realization of ultimate reality is one of the most challenging and important topics of Buddhist philosophical and contemplative theory and practice, the study of different approaches to accessing that realization directly bears upon and promises to contribute to the question of (un)mediated mystical experience. Therefore, although many elements involved in this polemical issue are uniquely Buddhist, their analysis can help us to achieve a better and more nuanced understanding of the issue of (un)mediated mystical experience. While only briefly addressing other forms of mystical experience in Buddhism, I will be targeting the issue of the process of realization of ultimate reality throughout this article.

In what follows below, I first address the broader question of mystical experience in its connection to Buddhism, focusing primarily on two dimensions of the Buddhist worldview: nature of mind and Buddhist paths. This discussion forms a general background for the analysis of Buddhist approaches to the realization of ultimate reality. My analysis specifically targets the ecumenical approach developed by the seminal 15th century Tibetan thinker Serdok Penchen Shakya Chokden (Tib. gser mdog panchen shākya mchog ldan, 1428-1507)3 with respect to the two major rival systems of Mahāyāna Buddhism-Madhyamaka (Middle Way) and Yogācāra (Yogic Practice). ${ }^{4}$ I elaborate on his main argument that despite contradictory worldviews, different types of contemplative conditioning leading to direct realization of ultimate reality, and conflicting descriptions of that realization, followers of both

2 Hereafter, for the Buddhist terms I will be providing only Sanskrit equivalents when such are available.

3 Hereafter, I am using the simplified phonetic transcription of Tibetan based on the usage adopted by the Tibetan and Himalayan Library. For details, see http://www.thlib.org/reference/transliteration

4 This seminal thinker occupies a unique place in the intellectual history of Mahāyāna Buddhism. Working during one of the most formative but least explored periods in Tibetan history, he was deeply involved in inter- and intrasectarian polemics of his time, and articulated a startlingly new reconsideration of the core areas of Buddhist thought and practice, such as epistemology, ethics, tantric rituals, and the relationship between philosophy and contemplation. One of the most complicated areas of Buddhist thought explored by Shakya Chokden in minute detail is the nature and relationship of Yogācāra and Madhyamaka. I focus on it in my Visions of Unity: The Golden Pandita Shakya Chokden's New Interpretation of Yogācāra and Madhyamaka (Albany, New York: State University of New York Press), forthcoming in 2011. Hereafter, Visions of Unity. 
Madhyamaka and Yogācāra can access the same direct meditative experience of emptiness that is not mediated by any words and concepts at the time when it actually occurs. This approach is especially intriguing and heuristically useful, providing new perspectives on the nature of non-conceptual experience of ultimate reality and the role conceptual processes play in initially triggering and subsequently articulating that experience. I connect my analysis of Shakya Chokden's position to the broader issue of how mediation might be involved in mystical experiences and the possibility of achieving the same mystical experience despite different conditioning processes leading to it.

My overall objective is to demonstrate that Buddhism offers highly advanced and sophisticated tools for addressing mystical experiences that have no exact parallels in the non-Buddhist discourse. Analysis and application of those tools will help better understand what issues related to mystical experience trouble Buddhist thinkers themselves and how they handle those issues. That in turn will result in a more nuanced and up-to-date understanding of the question of (un)mediated mystical experience addressed in contemporary scholarship on mysticism.

\section{Locating Buddhist mystical experiences}

\section{Multiplicity, contextuality, and the need for fine-tuning}

The question regarding whether there can be (un)mediated mystical experience has long been troubling scholars of religious studies..$^{5}$ This question is especially important to those who contest the possibility that followers of different religious traditions who have diverse backgrounds, follow different practices, and hold contradictory worldviews might achieve similar mystical experience(s). Claiming the possibility of unmediated mystical experience is important to those who believe in the existence of "religion" and "mysticism" as generic phenomena with definable characteristics, whose essence lies in personal experience, and whose manifestations are found in Buddhism, Christianity, and so forth. Denying this possibility is crucial to those who question the applicability of such categories, as well as narratives and theories designed for their explanation.

Over the past 30 years, polemics about mediated and unmediated mystical experience became heated, boiled, welled up, and spilled into the area of Buddhist thought and practice.

5 For the debate over this issue, see articles published in Steven T. Katz (ed.), Mysticism and Philosophical Analysis (New York: Oxford University Press, 1978), especially Katz's "Language, Epistemology, and Mysticism" in the same volume, pp. 22-74 (hereafter, "Language, Epistemology, and Mysticism"); and Robert K.C. Forman (ed.), The Problem of Pure Consciousness: Mysticism and Philosophy (New York: Oxford University Press, 1990), especially Forman's own "Introduction: Mysticism, Constructivism, and Forgetting" in that volume, pp. 3-49 (hereafter, "Introduction"). For further details of Forman's arguments, see Robert K.C. Forman, Mysticism, Mind, Consciousness (New York: State University of New York Press, 1999; hereafter Mysticism, Mind, Consciousness). For further details of Katz's position, see Steven Katz, "The 'Conservative' Character of Mystical Experience," in Mysticism and Religious Traditions, ed. Steven Katz (New York: Oxford University Press, 1983), 3-60, and Steven Katz, "Mysticism and the Interpretation of sacred Scripture," in Mysticism and Sacred Scripture, ed. Steven Katz (New York: Oxford University Press, 2000), 7-67. See also articles by contributors to the latter two volumes. For further references, see Forman's Mysticism, Mind, Consciousness, 2, 173-174. 
Both the attribution of "mystical" to "experience" and the emphasis on experience itself are problematic within the Buddhist context. Firstly, Buddhism lacks an equivalent of the term "mysticism." Secondly, even in such allegedly "mystical" Buddhist cultures as Tibetan, the role of experience is less important than theories of mystical experience suggest. ${ }^{7}$ Overall, Buddhism emphasizes realizations/insights into reality and abandonments of obscurations ${ }^{8}$ achieved through contemplation, ethical behavior, and ritual practice, while experience is assigned only secondary importance, usually as a by-product and indicator of the progress on the path. This is not to ignore the fact that Buddhists deal with multiple types of experiences that can be or already have been termed "mystical" by scholars of mysticism. Careful analysis of those experiences can greatly contribute to the broader field of religious studies. Nevertheless, if we do not want to turn mysticism into mystification, those experiences have to be handled with care and appreciated in their own right in terms of specific contextual meanings, emphases, and objectives. Only if these conditions are fulfilled can "mysticism" and "mystical experience" be released from the confines of quotation marks and addressed as if they were active and actual categories in Buddhism itself.

The terms "mysticism" and "mystical experience" are vague, and are used differently in different contexts. Their applicability to Buddhism is particularly questionable: neither have they been meaningfully used for translating or clarifying any Buddhist terms or ideas, nor can they easily fit into any Buddhist categories or concepts. Because they do not match the Buddhist worldview, I do not attempt to define them or even to sketch out their general characteristics. Nevertheless, I also believe we can use the vagueness of the terms "mysticism" and "mystical experience" to our advantage if our objective is to clarify the variety of

6 Similar to the study of "religion" as a separate field of inquiry, the topic of "mysticism" developed within the "Western" world. Partly because of that, when descriptions of mysticism are given, they are usually loaded with meanings, overtones, and agenda that are distinctly "Occidental" in character. The following statement by Robert Campany about religions is applicable to mysticism as well: "Discourse about religions is rooted in Western language communities and in the history of Western cultures... To speak of "religions" is to demarcate things in ways that are not inevitable or immutable but, rather, are contingent on the shape of Western history, thought, and institutions. Other cultures may, and do, lack closely equivalent demarcations." "On the Very Idea of Religions (in the Modern West and in Early Medieval China)," Journal of the American Academy of Religion, vol. 42, no. 4 (2003): 289.

7 For a critique of the overemphasis by some modern Buddhist apologists on the role of experience in Buddhism, see Robert H. Sharf's "Buddhist Modernism and the Rhetoric of Meditative Experience," Numen, vol. 42, no. 3 (1995): 228-283. But see also Janet Gyatso, "Healing Burns with Fire: The Facilitations of Experience in Tibetan Buddhism," in Journal of the American Academy of Religion, vol. 67, no. 1 (1999): 113-147 (hereafter, "Healing Burns with Fire"). Gyatso rightly observes that Sharf himself goes too far in his claim that the idea of unmediated meditative experience in Buddhism came from the western mentors of modern Asian apologists ("Healing Burns with Fire," 114), and in particular argues that his "claim that writing from personal experience is rare in Buddhism is also contravened by the Tibetan case" (ibid., 116).

8 For example, Vasubandhu states in his celebrated Treasury of Higher Knowledge (Abhidharmakośakārikā): "The Teacher's [i.e., the Buddha's] holy Dharma is twofold: // [It has] the nature of textual statements and realizations" (Skt. saddharmo dvividhah śāsturāgamādhigamātmakah). In Swāmī Dwārikādās Śāstrī (ed.), The Abhidharmakośa \& Bhāṣya of Ācārya Vasubandhu with Sphutārthā Commentary of Ācārya Yaśomittrā, vol. 2 (Varanasi: Bauddha Bharati, 1998), 31 (hereafter, The Abhidharmakośa \& Bhāșya). From this perspective, all instances of the Buddhist path will be seen as realizations themselves or auxiliaries and results of those realizations. 
phenomena these terms address rather than select only some phenomena as illustrations of limited definitions of the terms themselves. ${ }^{9}$

Furthermore, the category of "experience" in Buddhism is very complex. Buddhists use several terms that can be translated as "experience" but have different meanings when discussed together or addressed in specific contexts. Only some of these terms have meanings that overlap with the meaning of "realization," and it is realization that is emphasized even in such "experience-oriented" systems as Mahāmudrā (Tib. phyag chen, Great Seal) and Dzokchen (Tib. rdzogs chen, Great Perfection). When one is encouraged to personally taste, experience, and realize different elements of Buddhist teachings, it is not the experience per se that is being emphasized, but the fact that one has to "interiorize" those elements or discover them "within" oneself instead of treating them merely as external objects of intellectual study. Therefore, we should not confuse these referents of "experience" with any of the specific experiences of bliss, non-conceptuality, etc., that Buddhists often warn against forming attachment to and do not treat as unique objectives of their practice. The Mahāmudrā system, for example, addresses different types of direct insights or realizations (Tib. rtogs pa) into the nature of mind that can be preceded or accompanied by experiences of bliss, clarity, and non-conceptuality (Tib. bde gsal mi rtog pa'i nyams), but are separate from and superior to them. ${ }^{10}$ (Throughout the paper I am using the terms "realization of ultimate reality" and "experience of ultimate reality" interchangeably, because in that particular case Buddhist thinkers themselves can understand the term "experience" (Tib. nyams su myong $b a$ ) as "realization". ${ }^{11}$ )

Besides that, Buddhist thinkers and contemporary scholars of mysticism clearly pursue different objectives, have different interests, and operate within different conceptual frameworks. This is especially clear when we compare Buddhist approaches with those of the two prominent adversaries on the issue of (un)mediated mystical experience, Steven Katz and Robert Forman. Katz's position is best described in his own words: "There are NO pure (i.e., unmediated) experiences. Neither mystical experience nor more ordinary forms of experience give

9 I agree with Robert Gimello, who suggests caution in handling Buddhist subjects related to mysticism and meditation, but also argues that scholars who apply such efforts will be rewarded: "Not only will they thereby increase their store of information, but they may also discover, embedded in the studied traditions themselves, new categories of interpretation, new criteria of judgment. These, in turn, may not only better suit their Asian subjects, but may also prove cross-culturally more useful than their counterparts of western origin. In the case of mysticism or the contemplative life this is particularly to be anticipated." See Robert M. Gimello, "Mysticism and Meditation," in Mysticism and Philosophical Analysis, ed. Steven T. Katz (New York: Oxford University Press, 1978), 179-180 (hereafter, "Mysticism and Meditation"). Gimello himself prefers to take mystical experience in the Buddhist context narrowly, arguing that mystical experience as it is commonly understood is limited only to a particular type of Buddhist meditation, such as practices of calming, and that the terms "mystical" and "mysticism" should be restricted to the states of śamatha and samädhi that Buddhists themselves distinguish from and subordinate to discernment or vipaśyanā. Ibid., $188 \mathrm{ff}$.

${ }^{10}$ For details, see Dakpo Tashi Namgyal, Mahāmudrā: The Moonlight-Quintessence of Mind and Meditation (Boston: Wisdom Publications, 2006), 355 ff. (hereafter, Mahāmudrā). For the detailed analysis of this issue, see Janet Gyatso, "Healing Burns with Fire," $117 \mathrm{ff}$.

${ }^{11}$ For example, when Shakya Chokden uses such terms as "definitive meaning experienced through meditation" (Tib. sgom pas nyams su myong bya'i nges don), he treats the direct realization of ultimate reality as the experience of ultimate reality. (See note 66 for the full quotation.) 
any indication, or any grounds for believing, that they are unmediated." 12 Importantly, Katz adds that this process of mediation occurs during the experience itself, not only before or after. ${ }^{13}$ Forman, on the other hand, using Roland Fischer's "cartography" of conscious states, splits them into ergotropic and trophotropic, and tends to reserve the term "mysticism" only for trophotropic states that are marked by low levels of cognitive and psychological activity. ${ }^{14}$ He specifically focuses on the "pure consciousness event" (PCE), defining it as a "wakeful though contentless (nonintentional) consciousness," and further identifying it with what Walter Stace called "introvertive mysticism," distinguished from "extrovertive mysticism." 15

Both Katz and Forman tend to address mystical experience in general, although they do limit it to examples that suit their respective agendas. As Victor Hori rightly observes, to support his claim that all cases of mystical experience are contextually constructed, Katz systematically chooses only those reported cases of mystical experience that have intellectual content, while Forman never discusses reported cases of mystical experience that have much content. ${ }^{16}$ Larry Short also points out that arguing for the existence of the pure consciousness event, Forman, and those scholars who have joined him, attempt to "demonstrate that mystical experience is epistemologically extraordinary (that is, an exception to the general rule that consciousness is mediated), as a way of establishing the possibility of a common core to mystical experience." 17 Nevertheless, contemporary scholarship demonstrates that this divide itself is questionable. ${ }^{18}$ As soon will become apparent, Katz's and Forman's positions also cannot be easily applied to the Buddhist context. This is despite

12 “Language, Epistemology, and Mysticism”, 26. (Emphasis is the author’s own.)

${ }^{13}$ Ibid., 26-27.

${ }^{14}$ Forman, "Introduction," 5-7. In his Mysticism, Mind, Consciousness Forman has also included DMS (dualistic mystical state) into his study of mysticism. For further analysis and criticism of Forman's PCE and DMS see Randall Studstill, The Unity of Mystical Traditions: The Transformations of Consciousness in Tibetan and German Mysticism (Leiden: Brill, 2005), $26 \mathrm{ff}$.

15 Ibid., 8.

${ }^{16}$ Victor Sōgen Hori, "Kōan and Kenshō in the Rinzai Zen Curriculum," in The Koan: Texts and Contexts in Zen Buddhism, ed. (Oxford University Press, 2000), 282, 310 note 4. (Hereafter, "Kōan and Kenshō in the Rinzai Zen Curriculum.”)

${ }^{17}$ Larry Short, "Mysticism, Mediation, and the Non-Linguistic," Journal of the American Academy of Religion, vol. 63, no. 4 (1995): 670. (Hereafter, "Mysticism, Mediation, and the Non-Linguistic.")

${ }^{18}$ For a nuanced analysis of this debate, also described as the "constructivist-essentialist debate," see Martin T. Adam, “A Post-Kantian Perspective on Recent Debates about Mystical Experience," Journal of the American Academy of Religion, vol. 70, no. 4 (2002): 801-817. Adam questions the appropriateness of the experience / interpretation distinction that in his opinion presupposes the Kantian distinction between intuition and understanding, as well as noumenon and phenomenon. Victor Hori is also critical of this divide, approaching it from the Rinzai Zen perspective. He describes this divide as follows: "Katz and his opponents both agree in dividing the spectrum of consciousnesses into those with cognitive content and those without, into those that are mediated (not pure) and those that are unmediated (pure). They both assume that these categories are mutually exclusive and jointly exhaustive of all possibilities. They disagree only on whether there is or is not experience of pure consciousness" ("Kōan and Kenshō in the Rinzai Zen Curriculum," 282-283.) According to Larry Short, the argument about unmediated, pure consciousness is based on a false dilemma, because both Forman and Katz, despite their different approaches, restrict their discussion of mediation to the "sociolinguistic"; for example, all of Katz's samples consist of different sociolinguistic belief systems ("Mysticism, Mediation, and the Non-Linguistic," 661, 663). Short himself argues against limiting mediation to just that, and suggests that overall mediation is "not an obstacle to experience, but its sine qua non, and not a barrier to understanding, but the process of understanding" (ibid., 664). 
the fact that Buddhists do face similar problems in their approaches to what can be called "mystical experience."

Study of the tools and strategies used in Buddhist approaches to those problems and issues can significantly refine, expand, and modify contemporary debates about mystical experience. Similar to followers of other religious traditions, Buddhists emphasize the uniqueness of their practices and realizations, as well as their results, such as nirvāna. This being said, they also accommodate varieties of meditative states under the category of "mundane paths" (Skt. laukikamärga), ${ }^{19}$ thinking that those states are shared in common by Buddhist and non-Buddhist contemplatives. Arguing that one does not have to be a Buddhist to experience "infinite consciousness" (Skt. vijñānānatya), "nothingness" (Skt. akimcanya), and other states subsumed under that category, Buddhist thinkers show their insufficiency for attaining uniquely Buddhist objectives, and warn against confusing such states and uniquely Buddhist meditative states. ${ }^{20}$ Most importantly, Buddhist thinkers approach the question of mediation differently than either Katz or Forman: while the two scholars debate about the very possibility of unmediated mystical experience, the majority of Buddhist thinkers take for granted that certain states-such as the direct realization of ultimate reality and the omniscience of buddhahood-are not mediated by any conceptual images or verbal constructs at the time of their occurrence. ${ }^{21}$ This is despite the fact that they are necessarily mediated through specific Buddhist practices that precede them, and in cases other than buddhahood are also limited to realizing only some "parts" of reality. Buddhist thinkers also disagree on the question of whether the direct realization of ultimate reality has "content" and images, and involves mental processes. Therefore, Bud-

${ }^{19}$ See below. For the discussion of those states in the context of mystical experience, see Robert M. Gimello, :Mysticism and Meditation," 170-199; Paul J. Griffiths, "Pure Consciousness and Indian Buddhism," in The Problem of Pure Consciousness: Mysticism and Philosophy, ed. Robert K.C. Forman (New York: Oxford University Press, 1990), 71-97 (hereafter, "Pure Consciousness and Indian Buddhism"). For a detailed description of mundane paths, see Lati Rinbochay and Denma Lochö Rinbochay, Meditative States in Tibetan Buddhism (Boston: Wisdom Publications, 1983); Geshe Gedün Lodrö, Calm Abiding and Special Insight (Ithaca, New York: Snow Lion Publications, 1998); Florin Deleanu, The Chapter on the Mundane Path (Laukikamārga) in the Srāvakabhūmi: A Trilingual Edition (Sanskrit, Tibetan, Chinese), Annotated Translation, and Introductory Study, Studia Philologica Buddhica Monograph Series XXa, vol. 1-2 (Tokyo: The International Institute for Buddhist Studies, 2006); Longchen Rapjam (klong chen rab 'byams), Great Chariot: [Auto-]Commentary on the 'Mind Nature Revitalization of the Great Perfection' (Rdzogs pa chen po sems nyid ngal gso), vol. 2 (California: Yeshe De Project, 1994), 190-200. (Hereafter, Great Chariot.)

${ }^{20}$ See, for example, Longchen Rapjam, Great Chariot, vol. 1, 277-279, 404-406. Forman's accounts of PCE, for example, might agree with descriptions of certain meditative states accounted by Buddhist thinkers, but such states might be understood by those thinkers as mundane and not uniquely Buddhist in character. As Zeff Bjerken rightly observes in "Echoes of the Tibetan Buddhist bSam yas Debate in Current Controversies over Mystical Experience," The Tibet Journal, vol . 29, no. 4 (2004): 7 , "[t]he "empirical" accounts of the PCE recorded by Forman, including his own autobiographical report, might be criticized by Kamalaśila as blank states of pure calm (śamatha), which may be peaceful but they do not effect liberation."

${ }^{21}$ Note that in contrast to some non-Buddhist thinkers for whom non-mediation by words and concepts is only a small part of what might constitute mediation, most Buddhist thinkers treat such categories as time, space, subject-object intentionality, etc., as conceptually constructed. Demonstrating that a certain experience is not mediated by concepts will therefore automatically exclude it from being mediated by time, space, and other such constructs. 
dhists themselves hold divergent views on the meaning and process of mediation involved in mystical experiences.

These and other elements addressed below call for a more nuanced understanding of what Buddhists themselves believe to be common and uncommon experiences that can be termed "mystical," and how they understand the nature of those experiences. If we want the Buddhist approach to mystical experiences to be relevant to our discussion, it is important to make our discussion of mystical experiences relevant to Buddhism. In particular, we can greatly clarify the question of (un)mediated mystical experience in connection to Buddhism if we let Buddhist thinkers speak for themselves. They believe that Buddhist mystical experiences are conditioned by specifically Buddhist types of training. If we take those claims seriously, we have to shift our emphasis from the question of unmediated mystical experience per se to conditioning processes that precede and trigger it. Our question in that context will be to ask whether different conditionings necessarily lead to the same or different mystical experiences.

Similar to other religious traditions, in the Buddhist world, mystical experiences comprise a part of interwoven combinations of different elements or dimensions, such as epistemological models of conceptual and non-conceptual states of mind, models of the path to awakening, diverse cosmological models, distinctions between "esoteric" and "exoteric" elements, bodily transformations, and so forth. To fully appreciate Buddhist mystical experiences, therefore, it is crucial to consider all such related elements instead of just picking and choosing. Some dimensions necessarily play a more important role in particular mystical experiences than others. Due to limitations of this paper, I will focus on two such dimensions that are virtually ubiquitous throughout the Buddhist world and are particularly important in the present context: the dimension of mind ${ }^{22}$ structure and processes, and the dimension of the Buddhist paths (Skt. mārga). The former is indispensable for understanding how Buddhists themselves view mental processes involved in mystical experiences, while the latter is crucial for understanding what those experiences are embedded in, shaped by, limited to, and what role they play within the broader framework of Buddhist views and practices. ${ }^{23}$ The two dimensions are also interrelated, overlap, and cannot be treated in separation from each other: Buddhist paths are understood primarily as progressive mental states, while the majority of mental transformations related to mystical experiences, visions, and realizations in Buddhism can be understood only in the context of Buddhist paths.

${ }^{22}$ In this paper, I am taking the terms "mind" and "mental states" broadly, referring to all types of mental processes, including those that are given names of wisdom, primordial mind, non-dual wisdom, etc., as well as those that according to some thinkers transcend mind.

${ }^{23}$ Not all mystical experiences in Buddhism are directly related to Buddhist path structures: different types of pure visions, revelations, dawning of the clear light of death, postmortem visions of Buddhist divinities, etc., are not necessarily related to such structures, at least not explicitly. Nevertheless, paths to awakening are given in Buddhism more attention than in any other religion, and their analysis can make contributions to the studies of non-Buddhist religions as well. As Robert Buswell and Robert Gimello put it, “... we think that, as a potentially cross-cultural category for the study of religions, the concept of 'the path' has been given in Buddhism an explication more sustained, comprehensive, critical, and sophisticated than that provided by any other single religious tradition." Robert E. Buswell and Robert M. Gimello, "Introduction," in Paths to Liberation: The Mārga and Its Transformations in Buddhist Thought, ed. Robert E. Buswell and Robert M. Gimello (Honolulu: University of Hawaii Press, 1992), 2. 
The following short surveys of the Buddhist mind and path models are intended to introduce unfamiliar readers to the complexity of those models and demonstrate their close relationship with Buddhist experiences and realizations. This in turn will put into question the applicability to Buddhism of such foreign ideas and categories as Forman's category of contentless consciousness or Katz's assumption that all our experiences are necessarily constructed and mediated. Discussion of those models will also provide a necessary background and context for analyzing the interpretive approach of Shakya Chokden that will be given below. My overall objective is not to defend one particular model over another but to demonstrate their multiplicity and the indispensability of paying close attention to and utilizing specific Buddhist models when analyzing specific Buddhist mystical experiences, especially when those models are designed for not only explaining but in fact also leading to those experiences.

\section{Mind models}

Buddhists developed highly sophisticated models of the mind's structure and functioning, and use them in discussions of realizations of reality, meditative states, progress on the path, exalted visions, and awakening.

Mind in Buddhism is treated not as a reservoir containing thoughts and feelings, but rather as a framework of interrelated processes and mental states. The most common model is the twofold division of mind into cognitive states (Skt. citta) and mental factors (Skt. caitta). Cognitive states are usually subdivided into six-five sensory (Skt. indriyajñana) and one mental consciousness (Skt. manojñāna)—or eight, adding the afflicted mentality (Skt. kliștamanas) and storehouse consciousness (Skt. ālayavijñāna), as is usually done by Yogācāra thinkers. Mental factors are divided into 49, 51, etc., and further grouped into clusters, such as the 5 omnipresent mental factors (Skt. sarvatraga), 11 virtuous mental factors (Skt. kuśala), and so forth. ${ }^{24}$ Similar to the other seven types of consciousness, storehouse consciousness is always accompanied by the five omnipresent mental factors: mental contact (Skt. sparśa), attention (Skt. manaskāra), feeling (Skt. vedanā), discrimination (Skt. samjī̄a ), and intention (Skt. cetanā). ${ }^{25}$ Also, similar to other cognitive acts and mental factors, even the storehouse consciousness has objects of perception (Skt. älambana), such as the external world. ${ }^{26}$

These models are used to describe all unenlightened and enlightened states of mind, or limited to unenlightened states only. In the latter case, new elements can be added, such as the stainless consciousness (Skt. amalavijñāna), primordial mind (Skt. jñāna), primordial mind of luminosity (Skt. prabhāsvarajñāna), and buddha-essence (Skt. buddhagarbha).

\footnotetext{
${ }^{24}$ See, for example, Vasubandhu's Thirty Stanzas (Triṃsikākārikā), in Dan Lusthaus, Buddhist Phenomenology: A Philosophical Investigation of Yogācāra Buddhism and the Ch'eng Wei-shih Lun (London: RoutledgeCurzon, 2002), 276 ff., and the second chapter of his Treasury of Higher Knowledge (Abhidharmakośakārikā), in Swāmī Dwārikādās Śāstrī (ed.), The Abhidharmakośa \& Bhāṣya, 24 ff. See also Hsüan-tsang, Demonstration of Consciousness Only in Three Texts on Consciousness Only, translated by Francis H. Cook (Berkeley: Numata Center for Buddhist Translation and Research, 1999), $158 \mathrm{ff}$. (Hereafter, Demonstration of Consciousness Only).

${ }^{25}$ For details, see Hsüan-tsang, Demonstration of Consciousness Only, $68 \mathrm{ff}$.

${ }^{26}$ Ibid., 60 ff. See also Griffiths, "Pure Consciousness and Indian Buddhism," 84.
} 
Those elements then can be treated as becoming active/manifest during direct realizations of reality, buddhahood, and other circumstances when obscurations subside either temporarily or forever. In that context, some thinkers might take the primordial mind as self-cognizing and perceiving nothing else but the primordial mind itself. ${ }^{27}$ When no extra mental categories are added, or when they are subsumed under one of the six-fold or eight-fold categories, it might either be argued that realization of ultimate reality and awakening are performed by those cognitive states and mental factors, or are devoid of any mental states whatsoever and utterly inexpressible.

According to some thinkers, certain mental states last throughout lifetimes and can even continue into the state of buddhahood, while others are more short lived and disappear at a certain point either temporarily or forever. For example, according to Yogācāra, the storehouse consciousness persists continuously and perishes in the state of nirvāna ${ }^{28}$; the afflicted mentality temporarily ceases in a particular state of cessation (Skt. nirodhasamāpatti) and during direct realization of ultimate reality prior to nirvāṇa, and is completely eradicated in the state of an arhat. $^{29}$

Buddhist thinkers also provide dynamic models of mental states as unfolding processes. According to some Buddhist tantric systems, for example, worldly deluded states of consciousness develop on the basis of the primordially pure state of luminosity (Skt. prabhāsvara), fundamental innate luminous mind (Tib. gnyug ma lhan cig skyes pa'i 'od gsal gyi sems), and in the process of dying the order is reversed: all types of consciousness, including the storehouse consciousness, undergo successive stages of dissolution and vanish back into the basic luminosity at the moment of death just to reemerge again in the postmortem state. Tantric teachings provide elaborate descriptions of these processes with accompanying visions, and creatively incorporate them into contemplative practices. ${ }^{30}$ Likewise, some systems - such as the Chinese Hua-yen advocated by the Ch'an/Hua-yen thinker Kuei-feng Tsung-mi (780-841) and the "Quintessential Instructions" division (Tib. man ngag sde) of Tibetan Dzokchen advocated by Longchen Rapjam (Tib. klong chen rab 'byams, 1308-1364) and later elaborated upon by Jikmé Lingpa (Tib. 'jigs med gling pa, 1730-1798) - describe the basic reality as awareness (Ch. chih, Tib. rig pa), emphasize the dynamic nature of reality, and embrace the teaching of the nature-origination (Ch. hsingch'i) or nature-manifestation (Tib. gzhi snang) that bridges the gap between ultimate reality and phenomenal appearances, treating the latter as manifestations of the primordial nature due to its functioning (Ch. yung, Tib. rtsal). According to Dzokchen, awareness-also

${ }^{27}$ One such thinker is Shakya Chokden who describes the primordial mind interchangeably as self-cognition (Tib. rang rig, Skt. svasamvedana) and individually self-cognizing primordial mind (Tib. so so(r) rang gis rig pa'i ye shes). For details, see my Visions of Unity, Chap. 4, Sect. 1 and Chap. 5, Sect. 3. For a relevant analysis of self-cognition, see Zhihua Yao, The Buddhist Theory of Self-Cognition (London: Routledge, 2005), especially $121 \mathrm{ff}$.

${ }^{28}$ For details, see Hsüan-tsang, Demonstration of Consciousness Only, 78-81.

${ }^{29}$ For details, see ibid., 139-140.

${ }^{30}$ For details, see Lati Rinbochay and Jeffrey Hopkins, Death, Intermediate State and Rebirth in Tibetan Buddhism (Ithaca, NY: Snow Lion Publications, 1985). On how that process is incorporated into tantric practice, see Daniel Cozort, Highest Yoga Tantra: An Introduction to the Esoteric Buddhism of Tibet (Ithaca, New York: Snow Lion Publications, 1986; hereafter, Highest Yoga Tantra), and Yangchen Gawai Lodoe, Paths and Grounds of Guhyasamaja (Dharamsala, India: Library of Tibetan Works and Archives, 1995; hereafter Paths and Grounds of Guhyasamaja). 
called "fundamental mind" (Tib. gnyug sems)—forms the basis for all the eight types of consciousness mentioned above, and its realization cannot be performed by any other consciousness than that awareness itself. This fundamental awareness is also called "ground" (Tib. gzhi), because all impure and pure, enlightened states of consciousness arise from it due to its dynamic functioning. ${ }^{31}$

I should note that although the ground, awareness, and luminosity provide for and serve as the basis of the arising of phenomenal appearances, they do not contain them. Otherwise, we would have to accept an absurd possibility of the non-dualistic non-conceptual state of mind containing dualistic concepts, non-afflicted state having afflictions, etc. Because, as has been mentioned above, Buddhist thinkers do not treat mind as a thought container, the idea of emptying mind of its contents is hardly acceptable in the Buddhist context. ${ }^{32}$ It is more fruitful, therefore, to pay attention to what state ceases, what state persists, and at what level specific realizations and experiences occur. This adds an additional weight to distinctions between different types and levels of consciousness.

Certain models of mind can add new significance to philosophical and contemplative systems when these models are combined with each other. Yogācāra terminology of the eight types of consciousness, for example, can be carried into highly elaborate tantric systems and used as an aid in making subtle distinctions between different levels of consciousness utilized in tantric contemplative practice. ${ }^{33}$ Alternatively, it can be argued that because of divergent interpretations of mind in different systems, their practices and results of those practices are also vastly different. For example, it is often argued that tantric

${ }^{31}$ For details, see Peter N. Gregory, Inquiry into the Origin of Humanity: An Annotated Translation of Tsung-mi's Yüan jen lun with a Modern Commentary (Honolulu: University of Hawaii Press, 1995), 152-3, 179; and Sam Van Schaik, Approaching the Great Perfection: Simultaneous and Gradual Methods of Dzogchen Practice in the Longchen Nyingtig (Boston: Wisdom Publications, 2003), 51. (Hereafter, Approaching the Great Perfection.) For a detailed discussion of the dynamic development of different states of mind from the primordial base and their subsequent dissolution, as well as the nature and functioning of those mental states, see Longchen Rapjam's Great Chariot, vol. 1, 145174, 250-287. Note that despite some similarities in terminology and ideas, Hua-yen and Dzokchen systems are embedded in different cultural, historical, ritual, philosophical, and contemplative contexts that are not just non-responsive containers but rather active shapers of those systems. For example, despite its rhetoric of spontaneity and transcendence of "artificialities" of Tantra, Dzokchen is embedded in the tantric culture (although it is a question whether it always has been so), and the above mind model is only one part of the broader web of ideas and practices, such as unique Dzokchen preliminaries, visions of the Leap Over (Tib. thod rgal) stage, attainment of several types of Rainbow Body (Tib. 'ja'lus), and so forth, that do not exist in the Hua-yen system.

${ }^{32}$ One should not be misled by such examples scattered throughout Buddhist texts as an empty cave with thieves entering and exiting without finding anything inside (the example of a contemplative mind dissociated from occasional concepts that arise and subside by themselves), clear water with little fish frolicking within without agitating it (the example of maintaining one-pointed concentration while engaging in subtle analysis), and so forth. After all, these are just illustrations used for clarifying certain aspects of those contemplative states, not descriptions of their nature. Furthermore, the first example does not suggest that the cave is a reservoir of thieves. Nor does the second example suggest that similar to water containing fish one-pointed concentration somehow contains subtle analysis. All it points at is their mutually unobstructive union.

${ }^{33}$ See for example, Jamgön Kongtrul Lodrö Thaye, Creation and Completion: Essential points of Tantric Meditation (Boston: Wisdom Publications, 1996), 51-61 (hereafter, Creation and Completion). 
practice is highly efficient and swift because it teaches and utilizes subtle and powerful levels of consciousness that are even unheard of in non-tantric systems. ${ }^{34}$ Dzokchen meditation is built on making a sharp distinction between the fundamental mind of awareness and other types of consciousness, and then utilizing the former in contemplative practice. ${ }^{35}$ Kuei-feng Tsung-mi's argument for the superiority of the Ho-tse school of Ch'an's practice is based on his claim that in contrast to Northern and Hung-chou Ch'an lineages, it teaches awakening to both static and dynamic aspects of mind followed by their cultivation in contemplative practice. ${ }^{36}$

One distinction that is particularly helpful for understanding Buddhist approaches to mystical experiences - and specifically to the direct realization of ultimate reality-is the distinction between conceptual and non-conceptual types of mind. Although concepts and the lack thereof are understood by Buddhist thinkers differently, interpretive approaches inspired by the ideas of the famous Indian Buddhist logician Dharmakīrti (ca. 600-670 C.E.) assumed a place of paramount importance in the Indian and Tibetan Buddhist world. According to Tibetan interpreters of his system, conceptuality (Skt. kalpanā) is understood as a state of mind that cognizes its objects via their generic images or meaning-universals (Skt. arthasāmānya), ${ }^{37}$ while non-conceptual direct perception (Skt. pratyakșa) perceives its objects directly, without the media of those meaning-universals. Nevertheless, both conceptual and non-conceptual states of mind cognize their objects via "representations" (Skt. $\bar{a} k \bar{a} r a$ ), i.e., images of perceived things, which can be likened to reflections (representations) on the surface of a mirror (mind). The ontological status of those representations is understood differently even within the same Dharmakītean system, ${ }^{38}$ not to mention their different interpretations by subsequent thinkers. ${ }^{39}$

Dharmakīrti describes the transition from conceptual to non-conceptual understanding as follows: "... that to which one meditatively conditions oneself, whether it be real or unreal, will result in a clear, non-conceptual cognition when the meditation is perfected." 40 This very model is applied by Indian and Tibetan thinkers to conceptual and nonconceptual realization of reality and the process of transition from the former to the lat-

\footnotetext{
${ }^{34}$ See, for example, Daniel Cozort, Highest Yoga Tantra, $21 \mathrm{ff}$.

${ }^{35}$ For details, see Jeffrey Hopkins (trans. and ed.), Fundamental Mind: The Nyingma View of the Great Completeness by Mi-pam-gya-tso, Commentary by Khetsun Sangpo Rinbochay (Ithaca, New York: Snow Lion Publications, 2006), 39. See also Jamgön Kongtrul, Creation and Completion, $67 \mathrm{ff}$.

${ }^{36}$ Peter Gregory, "Sudden Enlightenment Followed by Gradual Cultivation: Tsung-mi's Analysis of Mind," in Peter Gregory (ed.), Sudden and Gradual: Approaches to Enlightenment in Chinese Thought (Honolulu: University of Hawaii Press, 1987), 298 ff. Hereafter, "Sudden Enlightenment Followed by Gradual Cultivation."

${ }^{37}$ See Anne Carolyn Klein and Geshe Tenzin Wangyal Rinpoche, Unbounded Wholeness: Dzogchen, Bon, and the Logic of the Nonconceptual (Oxford: Oxford University Press, 2006), 10, note 17 for discussion and further references related to the problems involved in translation of this term.

${ }^{38}$ Dharmakīti uses different levels of analysis wherein the status of those representations and the process of perception in general are interpreted differently. See John Dunne, Foundations of Dharmakìrti's Philosophy (Boston: Wisdom Publications, 2004), 53-144, especially 53-79, 100-112.

${ }^{39}$ See, for example, my Visions of Unity, Chap. 4, Sect. 1.

${ }^{40}$ John Dunne, "Realizing the Unreal: Dharmakīti's Theory of Yogic Perception," Journal of Indian Philosophy, vol. 34, no. 6 (December 2006): 514. Hereafter, "Realizing the Unreal."
} 
ter. $^{41}$ This process, nevertheless, is understood by Buddhist thinkers differently. Recently, John Dunne argued that Dharmakīrti himself did not view the transition from conceptual to non-conceptual realization of reality as some sort of a break through the veil of concepts to a mystical gnosis that experiences reality lying beyond concepts, but rather as a transition from conceptual understanding to a non-conceptual experience of the four noble truths. ${ }^{42}$ In Dharmakîrti's system, this process involves the sequence of cognitions induced initially by learning, then by contemplating, and finally by meditating (Skt. śrutamaya-, cintāmaya-, and bhāvanāmayajñāna). ${ }^{\prime 3}$ In contrast to that position, later Tibetan interpreters of Dharmakīrti's thought and other systems to which that thought was adopted often saw the transition from conceptual to non-conceptual realization of reality precisely as a break through conceptuality to the inconceivable and ineffable ultimate reality underlying and hidden beyond concepts. ${ }^{44}$

It is also true that virtually all Mahāyāna thinkers treat the highest ultimate reality and its direct realization as ineffable and transcending words and concepts. Nevertheless, the ineffability of the ultimate implies neither its similarity across different systems nor its accessibility. As some critics rightly observed, interpreters of mysticism can be misled by similar-sounding descriptions of mystical experience as ineffable, inexpressible, transcendent, sublime, and so forth. ${ }^{45}$ As I have recently argued, even within one and the same Buddhist culture, such as Tibetan, in the context of discussion of the same system, such as Madhyamaka, Buddhist thinkers offer multiple and contradictory interpretations of ineffable ultimate reality. ${ }^{46}$ As I will demonstrate below, Buddhist thinkers also conceive different ways of accessing the ultimate. Likewise, the direct realization of ultimate reality can be described as perceiving "something" or having no object at all. ${ }^{47}$ Because the direct realization of ultimate reality occupies the place of paramount importance in Buddhism, it comes as no surprise that Buddhist thinkers tend to argue that such interpretations do not just describe the same reality in different ways, but actu-

${ }^{41}$ For example, as The Fourteenth Dalai Lama Tenzin Gyatso puts it: "With respect to a non-conceptual wisdom that apprehends a profound emptiness, one first cultivates a conceptual consciousness that apprehends an emptiness, and when a clear perception of the object of meditation arises, this becomes a non-conceptual wisdom. Moreover, the initial generation of that conceptual consciousness must depend solely on a correct reasoning. Fundamentally, therefore, this process traces back solely to a reasoning, which itself must fundamentally trace back to valid experiences common to ourselves and others." Tenzin Gyatso, the Fourteenth Dalai Lama, The Key to the Middle Way: A Treatise on the Realization of Emptiness, in Tenzin Gyatso, the Fourteenth Dalai Lama, The Buddhism of Tibet (Ithaca, New York: Snow Lion Publications, 1987), 55-56.

${ }^{42}$ As Dunne puts it, "Dharmakīti does not choose to present yogic perception as a mystical gnosis that encounters or uncovers real things in the world; instead, he presents it as a process that is designed to inculcate transformative concepts into the mind through an intense, vivid and nonconceptual experience that arises from learning, contemplating and meditating on those concepts." Dunne, "Realizing the Unreal," 500.

${ }^{43}$ Ibid., 507.

${ }^{44}$ See the section on Shakya Chokden's approach to Yogācāra and Madhyamaka.

${ }^{45} \mathrm{Katz}$, "Language, Epistemology, and Mysticism," 46-47.

${ }^{46}$ See my "Encountering Ineffability — Counting Ineffability: On Divergent Verbalizations of the Ineffable in $15^{\text {th }}$ Century Tibet," in Acta Tibetica et Buddhica, vol. 1 (2008): 1-15.

${ }^{47}$ See also Griffiths, "Pure Consciousness and Indian Buddhism," 85-90, for the discussion of non-conceptual realization of the ultimate (Griffiths calls such a state of mind "unconstructed awareness"). 
ally shape mental processes in such a way that some of them can grant access to direct realization of that reality while others, being wrong and misleading, only obscure it.

\section{Buddhist paths}

The above discussion makes it clear that distinctions between different types and levels of mind are indispensable for understanding diverse approaches to meditation, progress in Buddhist practice, and by extension mystical experiences, because these distinctions directly bear upon such questions as what state of consciousness is used in what type of practice, how different mental states condition each other, and what experiences they trigger. Nevertheless, because mystical experiences in Buddhism for the most part are treated as results and stages of Buddhist practices, their discussion will remain overly vague and general unless placed within the framework of those practices. Buddhist practices in turn are often understood in terms of models of the path to awakening, such as the "five paths" (Skt. pañcamārga) model. Mahāyāna thinkers further add to it the "ten grounds" (Skt. daśabhümi), thereby issuing the model of "ten grounds-five paths" and presenting all of them as progressive stages of the path to buddhahood.

According to this model, one starts from the path of accumulation (Skt. sambhāramārga), moves on to the path of preparation (Skt. prayogamārga), and when for the first time one directly realizes the ultimate reality of all phenomena, one enters the path of seeing (Skt. darśanamārga) and the first bodhisattva ground, and becomes a Mahāyāna ārya or a "noble"/"exalted" being. One keeps practicing on the path of meditation (Skt. bhāvanāmārga) that covers bodhisattva grounds 2-10 and finally achieves the path of no more learning (Skt. aśaikșamārga), i.e., the state of buddhahood. Each of the ten grounds consists of a state of absorption in meditative equipoise (Skt. samāhita), when one directly realizes ultimate reality, and a state not in absorption, known as subsequent attainment (Skt. prșthalabdha), when one engages in other bodhisattva practices. ${ }^{48}$ Every transition from one ground to the next is necessarily conditioned by specific practices of the preceding ground known as "trainings" or "applications" (Skt. parikarman). ${ }^{49}$ According to the non-tantric Mahāyāna teachings, it takes at least three countless eons to cover all the five paths, requiring one countless eon to cover paths $1-2$, one countless eon to cover grounds $1-7$, and one more countless eon to cover grounds $8-10$.

This model explains when and why certain mystical experiences are believed to happen. The direct realization of ultimate reality can happen only during meditative equipoise on the path of seeing, meditation, and no more learning, and has to be preceded by a long process of conceptual contemplation of emptiness and other practices. At the very beginning of subsequent attainment that immediately follows most meditative equipoises, one experiences

${ }^{48}$ For details, see Mahāyāna Buddhism: The Doctrinal Foundations (New York: Routledge, 1989), $204 \mathrm{ff}$. by Paul Williams whose discussion is primarily based on the Sütra on the Grounds (Daśabhūmikasūtra). See also Longchen Rapjam, Great Chariot, vol. 1, 521-538, and vol. 2, 202-241.

${ }^{49}$ See Eugene Obermiller, Analysis of the Abhisamayālamkāra, Calcutta Oriental Series, no. 27 (London: Luzac \& Co., 1936), 149-178. Obermiller translates them as "appliances." 
the illusion-like meditative stabilization (Skt. māyopamāsamadhi) when conventional phenomena appear just as illusions, this experience being colored by the immediately preceding realization of emptiness. Besides this experience, subsequent attainments also contain multiple visions and experiences that can be termed "mystical" in the ecstatic sense: on each ground one sees an increasing number of buddhas, travels to an increasing number of pure lands, enters an increasing number of meditative absorptions, and so forth.

Buddhist path models also make it clear that despite similar terminology of "ultimate reality," "selflessness," and "emptiness," those terms have different referents in the context of specific paths, and can be applied to objects of yogic direct perception on the paths of śrāvakas, pratyekabuddhas, and bodhisattvas (the latter being the Mahāyāna path described above, the former two being non-Mahāyāna paths to arhatship). Buddhist thinkers often emphasize the hierarchy of direct realizations of emptiness and claim that only Mahāyāna āryas can realize ultimate reality fully, while śrāvakas and pratyekabuddhas are able to realize it only partially. ${ }^{50}$ Furthermore, during each of the ten grounds on the same Mahāyāna path, one acquires increasingly extensive visions of reality, similar to seeing the waxing moon. ${ }^{51}$

This is not to say that the mind and path models addressed above can be universally applied to all kinds of Buddhist mystical experiences. On the contrary, those models and their combinations themselves require tuning and reconsideration when applied to specific contexts. For example, when it is claimed that one can directly realize ultimate reality only starting from the level of ârya bodhisattvas that begins from the path of seeing, it follows that virtually no living Mahāyāna practitioners can claim to have realized ultimate reality directly. Otherwise, they would also have to claim that they have been practicing the Mahāyāna path in previous lives for at least one countless eon, can see at least a hundred buddhas, shake at least a hundred world realms, and so forth. On the other hand, followers of Dzokchen and Mahāmudrā systems repeatedly emphasize that from the very beginning of practice one has to be introduced and exposed to the ultimate nature of mind $d i$ rectly, and that even this initial realization is non-conceptual. ${ }^{52}$ But in the context of the ten grounds-five paths model this position raises the problems just mentioned above. In attempts to resolve such problems while retaining the ten grounds-five paths model, some Dzokchen and Mahāmudrā thinkers resorted to ideas of acquiring the not-yet-manifest potential to meet a hundred buddhas, shake a hundred realms, etc., that can be achieved in this very life but manifest after death when the "shell" of the body is finally broken, similar to a mighty mythical bird garuda whose powers are complete within the egg even before it hatches. ${ }^{53}$ But such interpretations are far from being universally accepted even within the Tibetan Buddhist world.

${ }^{50}$ See Eugene Obermiller, Prajñāpāramitā in Tibetan Buddhism (New Delhi: Paljor Publications, 1998), $13-54$.

${ }^{51}$ See Karl Brunnhölzl (tr. and introduction), In Praise of Dharmadhātu by Nāgārjuna, Commentary by the Third Karmapa (Ithaca, New York: Snow Lion Publications, 2007), 126, $273 \mathrm{ff}$.

${ }^{52}$ See, for example, Longchen Rapjam, Good Chariot: [Auto-]Commentary on the 'Illusion Revitalization of the Great Perfection' (Rdzogs pa chen po sgyu ma ngal gso' $i$ 'grel ba shing rta bzang po, California: Yeshe De Project, 1994), 221-236.

${ }^{53}$ See Sam Van Schaik, Approaching the Great Perfection, 124-127. See also Dakpo Tashi Namgyal, Mahāmudrā, 408-415. 
Furthermore, in spite of the popularity of the ten grounds-five paths model and the fact that many Buddhist writers feel obliged to refer to it in order to contextualize and authenticate views and practices they address, this is not the only model of the path. Kuei-feng Tsung-mi, for example, does not make reference to this model but uses his own model. He locates his approach to the path in the context of the three types of awakening-intrinsic awakening (Ch. pen-chüeh), awakening of initial insight (Ch. chieh-wu) characterized as sudden awakening (Ch. tun-wu), and awakening of complete realization (Ch. cheng-wu)and argues that genuine practice of the path starts with the awakening of initial insight only. Because he sees that awakening as sudden, he clearly does not feel that preparatory practices, such as those of the paths preceding the path of seeing in the ten grounds-five paths model, are necessary. ${ }^{54}$

Understanding which path models are implied in case of particular mystical experiences helps clear away a lot of confusion created by drawing overly generalized parallels not only between Buddhist and non-Buddhist mystical experiences, but also between mystical experiences addressed within different Buddhist traditions. ${ }^{55}$ For example, despite the fact that some Ch'an/Zen and Theravāda thinkers describe awakening as the goal of practice and as sudden, ${ }^{56}$ what is signified by "awakening" and "suddenness" can be vastly different depending on context. The awakening or "enlightenment" (Pali/Skt. bodhi) ${ }^{57}$ most Theravāda followers are striving for is understood as nirvāna of an arhat other than a buddha, ${ }^{58}$ while buddhahood is reserved only for outstanding individuals, such as the Buddha Sākyamuni. Such an arhatship is the fifth within the five paths that are not linked with bodhisattva practices as those are understood in Mahāyāna. Descriptions of Ch'an/Zen awakening, depending on context, might bypass the five path model or be embedded in it, but being a part of

${ }^{54}$ Peter Gregory, "Sudden Enlightenment Followed by Gradual Cultivation,” 279-313, especially 285.

${ }^{55}$ For the analysis of the tantric path model of the Guhyasamāja system, see Christian K. Wedemeyer, Āryadeva's Lamp that Integrates the Practices (Caryāmelāpakapradīpa): The Gradual Path of Vajrayāna Buddhism According to the Esoteric Community Noble Tradition (New York: The American Institute of Buddhist Studies, 2007), especially 63-120. On how it matches with the ten groundsfive paths model, see Yangchen Gawai Lodoe, Paths and Grounds of Guhyasamaja, $106 \mathrm{ff}$.

${ }^{56}$ For example, in his Zen and the Taming of the Bull: Towards the Definition of Buddhist Thought (London: Gordon Fraser, 1978), 15 ff., Walpola Rahula finds multiple parallels between Zen and Theravāda views and practices.

${ }^{57}$ I should note in passing that a lot of confusion was created by the term "enlightenment" and its careless application to diverse Buddhist and non-Buddhist systems. I am using "awakening" throughout this paper, partly in order to avoid confusion and partly because "awakening" approximates "bodhi" much better than "enlightenment." It is interesting to note that the term "enlightenment" was first applied to the Buddhist context by T.W. Rhys Davids (1843-1922), a Pali scholar and founder of the Pali Text Society. Rhys Davids translated "bodhi" as "Enlightenment" apparently wishing to associate the knowledge acquired by the Buddha with the knowledge of the European Enlightenment. See Judith Snodgrass, Presenting Japanese Buddhism to the West: Orientalism, Occidentalism, and the Columbian Exposition (Chapel Hill, North Carolina: The University of North Carolina Press, 2003), 106-107.

58 Technically speaking buddhas are arhats as well, but the term "arhat" nowadays is usually applied by Theravāda and Mahāyāna Buddhists to those who achieved nirvāṇa but did not develop many other exalted qualities attributed to buddhas only. 
the Mahāyāna tradition, Ch'an/Zen is necessarily linked with bodhisattva practices. Suddenness of an arhat's awakening mentioned in Theravāda texts means that sometimes such awakening happens unexpectedly, although it necessarily has to be preceded by years and sometimes lives dedicated to contemplative practice. In contrast, in the Ch'an/Zen-as in the case of the above-mentioned Tsung-mi's model-suddenness implies that no artificial conditioning can trigger initial awakening (although it does not imply that awakening just happens out of the blue).

What emerges from this discussion is that the issues of mediation, objects, and processes involved in mystical experiences are treated differently by Buddhist thinkers and assume various meanings in diverse contexts. According to the model of the six or eight types of consciousness and accompanying mental factors, mind always has certain objects of perception, and therefore no state of consciousness can be completely free from any objects and processes. Notice that even the above-mentioned states of "limitless consciousness" or "nothingness" are otherwise accompanied by more than a dozen mental factors, including volition or intention, and have objects. Some models that involve more than eight types of consciousness allow the possibility of actualizing the subliminal mind devoid of everything but ultimate reality and/or that mind itself. Nevertheless, Buddhist thinkers diverge on the issue of whether this ultimate reality is an object or not and what kind of object it is.

If we analyze the context in which Buddhist mystical experiences occur, it also becomes clear that they are triggered only by specific Buddhist training and conditioning. Even in the context of some Zen models that advocate initial awakening as sudden, this event is clearly mediated by certain conditioning processes that precede it, such as the contemplation of kōans in Rinzai training, for example. (Mediation, of course, does not necessarily have to precede mystical experiences immediately, but can occur at some time earlier.) In terms of the aforementioned Buddhist path models in particular, even the direct realization of reality never stays the same and constantly evolves until one is fully enlightened; realizations of emptiness and types of emptiness realized will differ depending on what path and stage of the path one is on. This implies that even this highest type of mystical experience in Buddhism is mediated-if not at the time of its occurrence then at least prior to it. It goes without saying that all pure visions of the subsequent attainment are both mediated and have objects.

The above discussion makes it clear that unless contextualized, analysis of (un)mediated mystical experience makes little sense in Buddhism; it is greatly assisted by the mind and path models, especially those of conceptuality/non-conceptuality and the ten stages-five paths. Within the Buddhist context, the direct realization of ultimate reality is one of the highest expressions of mystical experience, and it also best approximates the category of unmediated mystical experience. Direct realization of ultimate reality and other Buddhist mystical experiences are mediated in terms of being preceded by conditioning processes that bear upon and trigger those experiences. Whether such experiences are seen as mediated or not, objectless or not, etc., at the time of their occurrence, depends on particular forms of Buddhism we deal with, on contextual meanings, and on descriptive strategies used to address those experiences. 


\section{Shakya Chokden's approach to Yogācāra and Madhyamaka}

The previous section demonstrated that direct realization of ultimate reality and other uniquely Buddhist mystical experiences are seen by Buddhists as being accessible only through conditioning in the traditions that teach such experiences and realizations. Otherwise, they are not treated as uniquely Buddhist, and either placed under the category of the "mundane paths" mentioned above or seen as simply extraneous. Nevertheless, within the limits of Buddhist traditions themselves, certain mystical experiences, such as the realization of selflessness of persons (Skt. pudgalanairātmya), are often seen as being accessible to followers of all Buddhist systems because those systems provide efficient tools for their realization and because those tools do not seem to be contradictory.

Furthermore, Buddhist thinkers do believe that certain experiences and realizations can be accessed by different means. Although Buddhists often make minute distinctions between different views and practices, they also propose reconciliation of at least some of them. They might argue, for example, that there are several ways of accessing the subliminal level of consciousness, including direct realization of ultimate reality. Buddhist tantric systems address two distinct ways of accessing the fundamental innate luminous mind mentioned above: through initially dissolving subtle bodily energies into the central energy channel (and thus replicating the death process) and through direct exposure to that luminous mind itself. ${ }^{59}$ In other words, it can be accessed either after coarser levels of mentality have been stopped (through the dissolution of energies) or while still having them (in the case of direct exposure). In the non-Tantric context too, one can meditate on emptiness or selflessness of phenomena (Skt. dharmanairātmya) either having determined it through logical reasoning outlined in Madhyamaka treatises or through quintessential instructions on meditation. ${ }^{60}$

In other contexts, Tibetan thinkers of the Sakya (Tib. (sa skya), Nyingma (Tib. rnying $m a$ ), and Kagyü (Tib. bka' brgyud) traditions argue that both Svātantrika (Autonomist) and Prāsangika (Consequentialist) systems of Madhyamaka hold valid views on ultimate reality; thinkers of the Geluk tradition believe that the Prāsangika view of emptiness is shared by Buddhist Tantra, while such thinkers as Shakya Chokden demonstrate the equal validity of Nị̣svabhāvavāda Madhyamaka and Alīkākāravāda Yogācāra approaches to reality. It can also be argued that direct realization of reality does not necessarily have to be preceded by its conceptual understanding based on reasoning because tantric practitioners can access that realization by using alternative techniques, such as the wisdom-primordial mind em-

${ }^{59}$ See, for example, Tenzin Gyatso, the Fourteenth Dalai Lama, Kindness, Clarity, and Insight (Snow Lion Publications, 2006), $246 \mathrm{ff}$.

${ }^{60}$ See, for example, Rongtön Sheja Künrik (rong ston shes bya kun rig, 1367-1449), Lamp Clarifying the Five Paths: Quintessential Instructions on Incorporating into Experience the Essence of All Excellent Words - the Perfection of Wisdom (Gsung rab thams cad kyi snying po shes rab kyi pha rol tu phyin pa nyams su len pa'i man ngag / lam lnga gsal sgron, Gangtok, Sikkim: Sherab Gyaltsen, 1979), $11 \mathrm{ff}$. For more details on these instructions discussed by the same author, see Rongtön's Moonrays of Essential Points: Abridged Essence of Incorporation into Experience (Nyams su len pa' $i$ rim pa snying po mdor bsdus pa gnad kyi zla zer), in The Collected Works of Rong-ston Shak-kya Rgyal-mtsen, vol. B, kha (Dehra Dun, India: Sakya College, 1999), 562-565, and other meditative instructions in the same volume. 
powerment (Skt. prajñājñānābhișeka) and the stage of self-blessings (Tib. rang byin gyis brlabs pa'i rim pa). ${ }^{61}$

Restrictions nevertheless apply. For example, Buddhist thinkers argue that no progress on the path is possible unless one first generates renunciation of worldly existence, and no realizations on the Mahāyāna path are possible unless one has first developed the mind of awakening (Skt. bodhicitta). ${ }^{62}$ Nor is it possible to directly realize emptiness of all phenomena unless one uses specific Buddhist techniques for doing so. Likewise, Buddhist tantric thinkers argue that it is impossible to acquire genuine realizations on tantric paths without receiving tantric empowerments and instructions. The overall Buddhist position, therefore, is that although doors to some mystical experiences are at least partially open, not everybody can easily cross the threshold.

We should also note that tantric empowerments, renunciation, logical reasoning, etc., are much more than simply disposable tickets one has to buy in order to board Buddhist vehicles to awakening. On the contrary, they comprise important parts of those vehicles. Cultivation of bodhicitta, for example, does not just precede but necessarily accompanies Mahāyāna practices, and bodhicitta is carried all the way into the state of buddhahood. Tantric empowerments do not only initiate but are incorporated into tantric practice through visualizing oneself as a tantric deity accompanied on more advanced levels by self-empowerments (Tib. bdag 'jug). Furthermore, certain meditative states and experiences "make sense" only when conjoined with other practices. For example, direct realization of emptiness within the Mahāyāna context is believed to be brought about not by sole contemplation of reality, but by that contemplation in tandem with other Mahāyāna practices and states of mind, such as great compassion (Skt. mahākaruñā). ${ }^{63}$

The topic of Buddhist approaches to realization of ultimate reality is a part of this larger context. Although all Buddhist systems provide descriptions of reality and tools of realizing it, those descriptions and tools often conflict with each other and seem to be irreconcilable. As I have mentioned above, the dominant Mahāyāna position is that direct realization of ultimate reality is not mediated by words and concepts, although it is necessarily prepared by certain conditioning processes. In the non-tantric Mahāyāna Buddhism, these processes are usually considered to be conceptual, and consist of logical reasoning aimed at deconstructing and destroying dualistic thinking. The most complicated questions to ask in this context are how con-

${ }^{61}$ See his Rain of Ambrosia: Extensive [Auto-]Commentary on the 'Profound Thunder amidst the Clouds of the Ocean of Definitive Meaning' (Nges don rgya mtsho sprin gyi 'brug sgra zab mo'i rgyas 'grel bdud rtsi'i char 'bebs), in Two Controversial Mādhyamika Treatises (Bir, India: Yashodhara Publications, 1996), 362 and 376 (hereafter, Rain of Ambrosia); and Appearance of the Sun Pleasing All Thinkers: Discussion of the History of the Chariot Ways of [Dignāga's] 'Sūtra on Valid Cognition' and [its] Treatises (Tshad ma'i bstan bcos kyi shin rta'i srol rnams ji ltar 'byung ba'i tshul gtam du bya ba nyin mor byed pa'i snang bas dpyod ldan mtha' dag dga' bar byed pa), Collected Writings of Gser-mdog pan-chen Sākya-mchog-ldan, vol. 19 (Thimphu, Bhutan: Kunzang Tobgey, 1975), 102 (hereafter, Appearance of the Sun).

${ }^{62}$ See, for example, Ronald Davidson, "Atiśa's A Lamp for the Path to Awakening," in Buddhism in Practice (Princeton, NJ: Princeton University Press, 1995), 290-301.

${ }^{63}$ This unique active type of compassion to all living beings that is able to inspire the desire to attain buddhahood solely for their sake is believed to strongly affect and eventually become united with the realization of ultimate reality. 
ceptual processes can trigger non-conceptual realization, what the relationship between conceptuality and direct perception is, and whether different conceptual tools can trigger the same direct realization of reality.

These issues are greatly clarified by Shakya Chokden, whose interpretive approach illuminates key elements of the widespread Buddhist approach to non-conceptual experience of ultimate reality: that such experience is not mediated by words and concepts when it occurs; that it nevertheless has to be triggered by specific conditioning processes that usually involve words and concepts; and that those triggering processes can be different. His approach, therefore, is very useful for connecting analysis of the Buddhist position on this seminal type of mystical experience with the broader issue of mediation of mystical experiences that occupies contemporary researchers of mysticism.

More specifically, Shakya Chokden's contribution to the question of (un)mediated mystical experience lies in his unique interpretation of the nature and relationship of Yogācāra and Madhyamaka. In Tibet, these two rival systems are nearly universally viewed as the most important of all Buddhist philosophical traditions, although Madhyamaka is elevated to the top position. Shakya Chokden fully acknowledges differences between the two systems and provides a detailed analysis of their mutual polemical refutations of each other, but in his works written from 1477 onward $^{64}$ he ultimately argues for their fundamental compatibility and shared vision. The majority of Tibetan thinkers treat Madhyamaka as synonymous with the system of Nihsvabhāvavāda (Proponents of Entitylessness), and Yogācāra as synonymous with Cittamātra (Mind Only), and further subdivide the latter into two systems of Alīkākāravāda (Proponents of False Representations) and Satyākāravāda (Proponents of True Representations). ${ }^{65}$ In contrast, Shakya Chokden accepts neither that Yogācāra and Cittamātra are the same system nor that Madhyamaka is limited to the system of Nihsvabhāvavāda only. Although he accepts the twofold division of Yogācāra into Alīkākāravāda and Satyākāravāda, he identifies Satyākāravāda as synonymous exclusively with Cittamātra, and Alīkākāravāda as a subdivision of Madhyamaka on an equal footing with Niḥsvabhāvavāda and surpassing Cittamātra. His unique position is that Alīkākāravāda is both Yogācāra and Madhyamaka.

Clarifying differences between Alīkākāravāda and Nihsvabhāvavāda and at the same time showing their compatibility, he draws a sharp distinction between the views realized in the meditative equipoise of Mahāyāna āryas and the views conceptually determined by reasoning prior to meditative equipoise or described during its subsequent attainment. This distinction allows him to bring the two systems together on the level of direct realization of ultimate reality while keeping them distinct on the level of the conceptual approach to it. He shows that interpretive differences between Niḥsvabhāvavāda and Alīkākāravāda pertain to

\footnotetext{
${ }^{64}$ On the details of development of Shakya Chokden's views, see my Visions of Unity, Chap. 2, Sect. 4.

${ }^{65}$ The Satyākāravāda / Alīkākāravāda distinction ultimately boils down to the question of the reality of mental appearances. Although Yogācāras in general do not accept the existence of an external material world, according to Satyākāravāda its appearances or "representations" (Skt. ākāra) reflected in consciousness have a real or true existence, because they are of one nature with the really existent consciousness, their creator. According to Alīkākāravāda, neither external phenomena nor their appearances and types of consciousness that reflect them really exist and are therefore false. What exists in reality is only primordial mind described as self-cognition or individually self-cognizing primordial mind. This description is based on Shakya Chokden's interpretation. For details, see my Visions of Unity, Chap. 4, Sect. 1.
} 
the view of ultimate reality determined through reasoning on the conceptual level, but despite those differences they provide means for accessing the same ultimate reality directly realized through meditative experience. ${ }^{66}$ Consequently, by following different conceptual approaches to ultimate reality, followers of both systems can access the same direct realization of it. Likewise, he explains that descriptions of that realization on the level of its subsequent attainment are also distinct in the two systems. Nevertheless, both are equally valid divisions of Madhyamaka, because both have the capacity to dispel the most subtle obscurations and thereby enable the achievement of buddhahood. ${ }^{67}$

Comparing the two systems in the context of the self-emptiness (Tib. rang stong)/otheremptiness (Tib. gzhan stong) distinction, Shakya Chokden explains that Nị̣svabhāvavāda determines reality in terms of self-emptiness of all phenomena, while Alīkākāravāda does it in terms of other-emptiness. ${ }^{68}$ When determining the view of reality on the conceptual level, Nihsvabhāvavāda treats it as a total negation of the entities of all phenomena, including emptiness itself. In contrast to that, Alīkākāravāda selectively negates some phenomena (imaginary natures, Skt. parikalpita) on the basis of other phenomena (dependent natures, Skt. paratantra), and preserves the entity of non-dual primordial mind (thoroughly established nature, Skt. parinispanna), left as the remainder of that negation. ${ }^{69}$ The Niḥsvabhāvavāda position of self-emptiness entails the view of non-affirming negation (Skt. prasajyapratiședha), because it entails negation of all phenomena without positing anything in its stead. On the other hand, the Alīkākāravāda position of other-emptiness entails the view of affirming negation (Skt. paryudāsa), because it casts the non-dual primordial mind as the remainder of the negation of the object of negation. Shakya Chokden further argues that a non-affirming negation is an object of concepts only and therefore cannot be directly

${ }^{66}$ As he puts it at the beginning of his Rain of Ambrosia, the text that most extensively treats this issue: "I wish to explain the way in which there is a difference between the two systems in the modes of temporarily positing [their views] through reasoning, but no difference in their modes of upholding [the ultimate view] in the context of identification of the definitive meaning experienced through meditation" (srol gnyis po gnas skabs su rigs pas gtan la 'bebs tshul gyi khyad par yod pa dang / sgom pas nyams su myong bya'i nges don zhig ngos 'dzin pa'i tshe 'dzin tshul la khyad par med pa'i tshul bshad par 'dod pas...). Rain of Ambrosia, 390.

${ }^{67}$ Shakya Chokden explains: "Both [systems] are also similar in asserting that on the level of severing proliferations by the view within meditative equipoise, one does not take to mind any characteristics, and even the wisdom of individual analysis itself only has to be consumed by the fire of primordial mind. Nevertheless, on [the level of] subsequent attainment, when they present tenets in their own systems, [they differ in] accepting non-dual primordial mind or not accepting it. Therefore, due to that lack of difference in their modes of severing proliferations within meditative equipoise, it is not possible to distinguish between ability or non-ability to abandon predispositions of obscurations of knowables by the views of the two systems" (gnyis kas kyang mnyam gzhag tu lta bas spros pa gcod pa' $i$ tshe mtshan ma gang yang yid la mi byed cing / so sor rtog pa'i shes rab nyid kyang ye shes kyi mes bsreg dgos pa nyid du bzhed par mtshungs kyang / rjes thob tu rang lugs su grub pa'i mtha'smra ba na / gnyis med kyi ye shes yod par khas len pa dang / de mi len pa'o // de bas na mnyam gzhag tu spros pa gcod tshul la khyad par med pa de'i phyir lugs gnyis ka'i lta ba la shes sgrib kyi bag chags spong nus mi nus kyi khyad par dbye nus pa ma yin no). Thorough Clarification of Definitive Meaning of the Five Doctrines of Maitreya (Byams chos lnga'i nges don rab tu gsal ba zhes bya ba' $i$ bstan bcos), Collected Writings of Gser-mdog paṇ-chen Sākya-mchog-ldan, vol.11 (Thimphu, Bhutan: Kunzang Tobgey, 1975), 19-20.

${ }^{68}$ Rain of Ambrosia, 379.

${ }^{69}$ Ibid., 333-334. 
experienced in the meditative equipoise of Mahāyāna āryas. The affirming negation can be experienced directly in meditative equipoise, because the self-cognizing primordial mind is both an affirming negation and a functional thing (Tib. dngos po).$^{70}$

Thus, Alīkākāravādins conceptually determine through reasoning and meditate directly in meditative equipoise on the same primordial mind. They describe that realization afterwards also as meditation on the primordial mind. Nị̣svabhāvavādins through reasoning arrive at the non-affirming negation and afterwards claim that the non-realization of anything by anything is simply given the name of direct realization of emptiness. Nevertheless, both the Alīkākāravāda view of affirming negation and the Niḥsvabhāvavāda view of non-affirming negation are effective in terms of being able to trigger the same direct realization of ultimate reality. Despite differences in techniques used for accessing that realization, followers of both systems directly realize the same reality as a result of applying those techniques. This sameness is not damaged by the fact that Alīkākāravādins afterwards describe that realization as an affirming negation while Niḥsvabhāvavādins describe it as not realizing anything by anything (they cannot describe it as a non-affirming negation because that would entail that such realization is conceptual).

Shakya Chokden argues that followers of both Niḥsvabhāvavāda and Alīkākāravāda are "destined" to directly realize the same ultimate reality. No matter which of the two systems one follows, she eventually will break through the thicket of conceptuality and directly experience the same non-dual primordial mind. But we also learned that Niḥsvabhāvavāda negates the reality of all phenomena, including the primordial mind, while Alīkākāravāda does not negate its reality. Then how can the two systems be compatible? Shakya Chokden's answer is that whether their followers negate reality of primordial mind prior to meditative equipoise or not, they can get access to this primordial mind within meditative equipoise. This position raises the following question: how is it possible to negate grasping at the reality of primordial mind without negating it through reasoning? Shakya Chokden handles this question by arguing that there are two different ways of negating grasping: using reasoning that focuses on negating the objects of grasping and using reasoning that focuses on negating the grasping itself. ${ }^{71}$ The first approach is used by Nị̣svabhāvavādins, the second by Alīkākāravādins.

${ }^{70}$ Ocean of Scriptural Statements and Reasoning: Treasury of Ascertainment of Mahāyāna Madhyamaka (Theg pa chen po dbu ma rnam par nges pa'i bang mdzod lung dang rigs pa'i rgya mtsho), Collected Writings of Gser-mdog paṇ-chen Śākya-mchog-ldan, vol.14 (Thimphu, Bhutan: Kunzang Tobgey, 1975), 393; ibid., vol.15, 461; Great Path of Ambrosia of Emptiness: Explanation of Profound Pacification Free from Proliferations (Zab zhi spros bral gyi bshad pa stong nyid bdud rtsi'i lam po che), Collected Writings of Gser-mdog paṇ-chen Śākya-mchog-ldan, vol.4 (Thimphu, Bhutan: Kunzang Tobgey, 1975), 114; Appearance of the Sun, 85.

${ }^{71} \mathrm{He}$ explains: "There are two types of reasoning negating adhering minds together with habitual tendencies: the reasoning that negates grasping at objects by having negated those objects in the face of conceptuality, or [the reasoning negating] only the apprehender-imaginary nature by the reason of the lack of being one or many" (zhen blo bag chags dang bcas pa // 'gog byed rigs pa'i rnam grangs gnyis // rtog ngor de yul bkag pa yis // de 'dzin 'gog pa'i rigs pa dang // yang na 'dzin pa kun btags nyid // gcig dang du bral rigs pas so). Precious Treasury of the Condensed Essence of the Profound and Extensive in Eight Dharma Sections (Zab rgya'i snying po bsdus pa rin chen gter mdzod chos tshan brgyad pa), in 'Hundred and Eight Dharma Sections' Treatise (Chos tshan brgya dang brgyad pa zhes bya ba'i bstan $b c o s$ ), Collected Writings of Gser-mdog pan-chen Śākya-mchog-ldan, vol. 13 (Thimphu, Bhutan: Kunzang Tobgey, 1975), 174. 
Describing the tools that negate conceptual proliferations, Niḥsvabhāvavādins argue that without negating the object, its subject cannot be negated. This is because the Nị̣svabhāvavāda system treats subjects and objects as dependently established. Because they are established in mutual dependence, they have to be negated in mutual dependence too. According to the Alīkākāravāda system, on the other hand, it is possible to negate grasping at objects by negating just subjects that grasp. One does not necessarily have to negate the objects those subjects grasp at. In other words, by negating grasping subjects, their grasping function will be cancelled automatically. We might think of cutting off a hand as an analogy: the moment it is cut off its grasping or grabbing function stops on its own accord, without unnecessary removal of objects of grabbing. In particular, it is possible to negate grasping at reality of primordial mind by negating consciousness that takes primordial mind as its object and grasps at it as real. Shakya Chokden treats both the Nihsvabhāvavāda and Alīkākāravāda approaches as valid and argues that it is possible to abandon all obscurations by following either one. ${ }^{72}$

Highlighting this sharp distinction between Niḥsvabhāvavāda and Alīkākāravāda views of emptiness on the conceptual level, Shakya Chokden demonstrates that they are different Madhyamaka systems. In spite of that, he argues that this difference itself does not go beyond conceptually determined views. Even though on the conceptual level followers of the two types systems determine emptiness differently, both of them abandon the same proliferations and acquire the same direct realization of ultimate reality within the meditative equipoise of Mahāyāna āryas. ${ }^{73}$ Put in terms of mystical experience, his position is that at least within the limits of these two systems, Mahāyāna āryas acquire the same mystical experience of ultimate reality that is not mediated by any concepts or words at the time of its occurrence. This is despite the fact that it is necessarily mediated prior to its occurrence, i.e., prepared and triggered by different conceptual tools, and its subsequent description is also affected by divergent philosophical categories of the two systems.

\section{Conclusion and final remarks}

It is clear that Shakya Chokden's position hinges upon his basic claim that both Niḥsvabhāvavāda and Alīkākāravāda approaches are efficient for dispelling obstacles to direct realization of ultimate reality. As we have seen, he argues that it is possible to

\footnotetext{
72 This is how he presents them in the Rain of Ambrosia: "Honorable Candrakīti and other [Niḥsvabhāvavādins] assert that without determining the object, the dharma-sphere, as self-empty, it is impossible to reverse thoughts that grasp at it as signs. On the other hand, honorable Asanga, commenting on Maitreya's scriptures, [asserts that] having determined the apprehender-imaginary nature as self-empty, and accustomed [one's mind to it], due to that very [process] the grasping [at the dharma-sphere] can subside by itself within meditative equipoise" (yul chos dbyings rang stong du gtan la ma phab na / de la mtshan mar 'dzin pa'i blo ldog mi nus zhes pa ni zla ba'i zhabs sogs kyi bzhed pa yin mod / thogs med zhabs kyis byams pa'i gzhung 'grel ba na ni / 'dzin pa kun btags rang stong du gtan la phab nas goms par byas pa nyid kyis mnyam gzhag tu 'dzin pa rang gi ngang gis zhi bar nus...). Rain of Ambrosia, 415. See also the Appearance of the Sun, vol. 19, 118-119 for more details.

${ }^{73}$ Rain of Ambrosia, 334.
} 
negate the same obstructing concepts by focusing on either negating their referents (as Niḥsvabhāvavādins do) or those concepts themselves (as Alīkākāravādins do). To translate this position into the "mystical language," he claims that one can access the same mystical experience of reality in different ways as long as those ways are equally effective for destroying obstacles to that experience. What allows Shakya Chokden to make such claims?

A crucial point to note here is that his claim of the same non-conceptual mystical experience being triggered by different conceptual processes is possible only as long as those processes are treated as deconstructive in nature. As an example, we can think of demolishing a wall: whether one uses bare hands, feet, hammers, sledges, explosives, etc., as long as he can completely demolish it, he will achieve the same end result-disappearance of the wall and breaking through it to the open space it has been blocking. Likewise, as long as techniques used by Niḥsvabhāvavāda and Alīkākāravāda practitioners are treated as deconstructive, and as long as it can be demonstrated that they are equally effective in destroying impediments to the direct realization of reality, it can be claimed that the direct realization they trigger and the reality accessed through that realization are the same.

Such claims would be unfounded were Shakya Chokden treating the processes leading to direct realization of reality - as well as that realization itself-as constructive, i.e., consisting of building, developing, and strengthening different ideas and concepts, be they concepts of ultimate reality, emptiness, primordial mind, and what not. Were he to argue that Niḥsvabhāvavāda and Alīkākāravāda contemplatives engage in constructing and augmenting discordant ideas as the means of realizing their respective versions of ultimate reality, how would he be able to claim that despite constructing and cultivating those different ideas in contemplative practice, Niḥsvabhāvavāda and Alīkākāravāda practitioners can somehow achieve the same realization as a result of that practice? It would be similar to claiming that a person who meditates on a white square and a person who meditates on a red triangle can achieve a vivid vision of one and the same phenomenon as a result of those meditations. Another example we can think of is constructing different houses with different materials, giving them different shapes and sizes, and painting them with different colors. To claim that such construction activities can somehow result in building absolutely identical houses would indeed be mystical!

Note another important element of Shakya Chokden's approach: he is far from claiming that all mental impediments can be destroyed with any deconstructive technique. After all, is it possible to destroy all types of walls with just any tools? Of course not! Shakya Chokden's position is likewise much more specific and restrictive: he is claiming that in the non-tantric context only Niḥsvabhāvavāda and Alīkākāravāda tools are sufficient for destroying impediments to direct realization of ultimate reality. And here he is not different from other Tibetan thinkers who also treat systems "lower" than Madhyamaka as insufficient for achieving this objective because according to them those "lower" systems do not provide valid means for destroying impediments to that realization. In fact, this is one of the main reasons why Shakya Chokden works so hard to demonstrate in his writings that Alīkākāravāda Yogācāra is Madhyamaka and not Cittamātra: treating it as Cittamātra (or any other system below Madhyamaka) would immediately exclude it 
from the category of those systems that provide effective means for realization of ultimate reality.

The lesson we learn from Shakya Chokden, therefore, is much more nuanced than something along the lines of "different traditions can bring their followers to the same mystical experience despite the fact that they describe such experience differently." Rather, his position suggests that in order to understand whether, when, and how followers of different traditions can achieve similar mystical experiences, we have to analyze the deconstructive processes that they utilize in contemplative practice. Were those processes not deconstructive, any claims of common mystical experiences achieved as their result would be groundless.

Consequently, besides exploring the questions of whether mystical experiences are constructed or not and whether they are mediated or not, we also have to explore in more detail the actual processes leading to those experiences. If we want to explore similarities between different mystical traditions-including those that claim their mystical experiences are unmediated at the time of their occurrence-we have to analyze what their followers attempt to deconstruct, what they claim to have deconstructed, and most importantly what tools they use to achieve that deconstruction. If it is possible to demonstrate that those tools are equally effective, we might go ahead and claim that despite different cultures, backgrounds, worldviews, etc., followers of those traditions can achieve the same mystical experience. Otherwise, we might as well be satisfied to conclude that they simply have irreconcilable differences and particularities. But obviously a survey of that breadth is beyond the scope of this paper.

The approach outlined here is, I believe, beneficial in several respects. First, it provides an alternative way of analyzing the issue of (un)mediated mystical experience by shifting our attention from the question of the possibility of such an experience to the actual techniques designed to induce it. Second, it takes us beyond the boundaries of the "Western" intellectual world, drawing our attention to perspectives on mystical experience developed by Buddhists such as Shakya Chokden who-together with numerous thinkers from other Asian religious traditions-concur that it is possible to have a non-conceptual, unmediated experience of their version of the ultimate that nonetheless has to be intentionally triggered by particular contemplative techniques. ${ }^{74}$ And last, but not least, it might take us beyond purely textual studies of mysticism to the world of field research that would consist of observing contemplative techniques practiced by followers of different traditions, discussing with them their experience of relationship between those contemplative processes and their

\footnotetext{
74 See Richard King, Orientalism and Religion: Post-Colonial Theory, India and "The Mystic East" (New York: Routledge, 1999), 175 ff. Discussing approaches of Indian religious traditions, King rightly argues: "All of these Asian traditions accept the role played by concepts and cultural conditioning in everyday states of consciousness. Clearly, they also accept that releasing oneself from these conditioning factors requires cultivation through constant yogic practice... Where these traditions differ from modern Western intellectuals like Katz... is in the acknowledgement of the possibility of transcending one's own personal and cultural particularity and the attainment of some final state of ultimate understanding... The acceptance of the reality (indeed, for these Indian traditions the centrality) of an unmediated and unconstructed awareness constitutes a major point of disagreement between mainstream Western intellectual thought and classical Asian traditions of spirituality" (ibid., 182).
} 
intended results, and perhaps even personally participating in those practices as a means of personal intimate understanding.

This article was primarily concerned with what Buddhists themselves have to say about-and contribute to-the question of (un)mediated mystical experience. It is selfevident that similar to varieties of mystical experiences that emerge as a result of specific conditioning used in other religions, in Buddhism too there are reported different mystical experiences that are conditioned by uniquely Buddhist techniques. The problematic question raised in this article was whether Buddhism allows for unmediated mystical experiences. In my analysis of the processes involved in the key Buddhist mystical experience-direct realization of ultimate reality-I argued that most Buddhist thinkers (represented in this paper by Shakya Chokden) treat this experience as unmediated by words and concepts at the time of its occurrence. Nevertheless, such realization is seen as necessarily mediated in terms of being triggered by preceding conditioning processes that are uniquely Buddhist in character.

Buddhists diverge in their interpretations of the nature of ultimate reality and the processes leading to its realization. The main question targeted throughout this article was whether, despite that diversity, Buddhism allows for the same mystical experience to be triggered by different conditioning processes. My analysis of Shakya Chokden's position demonstrated that according to at least some thinkers this is possible, but only in limited cases, such as those of Alīkākāravāda and Niḥsvabhāvavāda.

This article was not concerned with possible commonalities between Buddhist and nonBuddhist mystical experiences in general (except for the category of "mundane paths" that Buddhists take as common to themselves and some groups of non-Buddhist contemplatives). Analysis of the direct realization of ultimate reality in terms of Buddhist mind and path models demonstrates that it is necessarily triggered by uniquely Buddhist means. In contrast to the Alīkākāravāda and Niḥsvabhāvavāda approaches addressed above, we cannot claim the sameness of this particular mystical experience in Buddhism and other religions. The reason is that the Alīkākāravāda and Nị̣svabhāvavāda systems rely on conditioning processes based on reasoning aimed at the deconstruction of concepts; as long as it can be demonstrated that their reasoning is equally valid, it is also possible to claim that it can eventually bring about the same mystical experience-the direct realization of ultimate reality. This is clearly not the case in other religious systems that provide neither such reasoning nor conditioning processes based on that reasoning. And even in the Buddhist context, such an option is open within the narrow confines of some Mahāyāna traditions only.

Nevertheless, this research might be profitably extended by exploring whether certain specific practitioners within certain Buddhist and non-Buddhist traditions might share at least some types of mystical experience. It is too early to anticipate any specific results at this point. But even if such research demonstrates more differences than similarities, more plurality than commonality between the mystical experiences of different traditions, that finding itself might be significant and serve an important purpose. 


\section{References}

Adam, Martin T. (2002). A post-kantian perspective on recent debates about mystical experience. Journal of the American Academy of Religion, 70(4), 801-817.

Bjerken, Z. (2004). Echoes of the Tibetan Buddhist bSam yas debate in current controversies over mystical experience. The Tibet Journal, 29(4), 3-18.

Brunnhölzl, K. (tr. and introduction) (2007). In Praise of Dharmadhātu by Nāgārjuna, Commentary by the Third Karmapa. Ithaca, New York: Snow Lion Publications.

Buswell, R. E., \& Gimello, R. M. (1992). Introduction. In R. E. Buswell \& R. M. Gimello (Eds.), Paths to Liberation: The Mārga and Its Transformations in Buddhist Thought (pp. 1-36). Honolulu: University of Hawaii Press.

Campany, R. F. (2003). On the Very idea of religions (in the modern West and in early medieval China). Journal of the American Academy of Religion, 42(4), 287-319.

Cook, F. H. (tr.). (1999). Three Texts on Consciousness Only. Berkeley: Numata Center for Buddhist Translation and Research.

Cozort, D. (1986). Highest Yoga Tantra: An Introduction to the Esoteric Buddhism of Tibet. Ithaca, New York: Snow Lion Publications.

Dakpo Tashi Namgyal (2006). Mahāmudrā: The Moonlight-Quintessence of Mind and Meditation. Boston: Wisdom Publications.

Deleanu, F. (2006). The Chapter on the Mundane Path (Laukikamārga) in the Śrāvakabhūmi: A Trilingual Edition (Sanskrit, Tibetan, Chinese), Annotated Translation, and Introductory Study. Studia Philologica Buddhica Monograph Series XXa, vol. 1-2. Tokyo: The International Institute for Buddhist Studies.

Dunne, J. (2004). Foundations of Dharmakirti's Philosophy. Boston: Wisdom Publications.

Dunne, J. (2006). Realizing the unreal: Dharmakīrti's theory of yogic perception. Journal of Indian Philosophy, 34(6), 497-519.

Dwārikādās Śāstrī, S. (ed.). (1998). The Abhidharmakośa \& Bhāṣya of Ācārya Vasubandhu with Sphutārthā Commentary of Ācārya Yaśomittrā . (2 vol.) Varanasi: Bauddha Bharati.

Forman, R. K. C. (1990a). The Problem of Pure Consciousness: Mysticism and Philosophy. New York: Oxford University Press.

Forman, R. K. C. (1990b). Introduction: Mysticism, Constructivism, and Forgetting. In R. K. C. Forman (Ed.), The Problem of Pure Consciousness: Mysticism and Philosophy (pp. 3-49). New York: Oxford University Press.

Forman, R. K. C. (1999). Mysticism, Mind, Consciousness. New York: State University of New York Press.

Geshe Gedün Lodrö (1998). Calm Abiding and Special Insight. Ithaca, New York: Snow Lion Publications.

Gimello, R. M. (1978). Mysticism and Meditation. In S. T. Katz (Ed.), Mysticism and Philosophical Analysis (pp. 170-199). New York: Oxford University Press.

Gregory, P. (1987). Sudden Enlightenment Followed by Gradual Cultivation: Tsung-mi's Analysis of Mind. In Gregory Peter (Ed.), Sudden and Gradual: Approaches to Enlightenment in Chinese Thought (pp. 279313). Honolulu: University of Hawaii Press.

Gregory, P. (1995). Inquiry into the Origin of Humanity: An Annotated Translation of Tsung-mi's Yüan jen lun with a Modern Commentary. Honolulu: University of Hawaii Press.

Griffiths, P. J. (1990). Pure Consciousness and Indian Buddhism. In R. K. C. Forman (Ed.), The Problem of Pure Consciousness: Mysticism and Philosophy (pp. 71-97). New York: Oxford University Press.

Gyatso, J. (1999). Healing burns with fire: the facilitations of experience in Tibetan Buddhism. Journal of the American Academy of Religion, 67(1), 113-147.

Heine, S. \& Wright, D. S. (ed.). (2000). The Koan: Texts and Contexts in Zen Buddhism. Oxford University Press.

Hopkins, J. (trans. and ed.). (2006). Fundamental Mind: The Nyingma View of the Great Completeness by Mi-pam-gya-tso, Commentary by Khetsun Sangpo Rinbochay. Ithaca, New York: Snow Lion Publications. 
Hori, V. S. (2000). Kōan and Kenshō in the Rinzai Zen Curriculum. In S. Heine \& D. S. Wright (Ed.), The Koan: Texts and Contexts in Zen Buddhism (pp. 280-315). New York: Oxford University Press.

Hsüan-tsang (1999). Demonstration of Consciousness Only. In Three Texts on Consciousness Only, translated by Francis H. Cook, 1-370. Berkeley: Numata Center for Buddhist Translation and Research.

Jamgön Kongtrul Lodrö Thaye (1996). Creation and Completion: Essential Points of Tantric Meditation. Boston: Wisdom Publications.

Katz, S. T. (1978a). Language, Epistemology, and Mysticism. In S. T. Katz (Ed.), Mysticism and Philosophical Analysis (pp. 22-74). New York: Oxford University Press.

Katz, S. T. (Ed.). (1978b). Mysticism and Philosophical Analysis. New York: Oxford University Press.

Katz, S. T. (Ed.). (1983a). Mysticism and Religious Traditions. New York: Oxford University Press.

Katz, S. T. (1983b). The 'Conservative' Character of Mystical Experience. In S. Katz (Ed.), Mysticism and Religious Traditions (pp. 3-60). New York: Oxford University Press.

Katz, S. T. (2000a). Mysticism and the Interpretation of Sacred Scripture. In S. Katz (Ed.), Mysticism and Sacred Scripture (pp. 7-67). New York: Oxford University Press.

Katz, S. T. (Ed.). (2000b). Mysticism and Sacred Scripture. New York: Oxford University Press.

King, R. (1999). Orientalism and Religion: Post-Colonial Theory, India and "The Mystic East.. New York: Routledge.

Klein, A. C., \& Rinpoche, G. T. W. (2006). Unbounded Wholeness: Dzogchen, Bon, and the Logic of the Nonconceptual. Oxford: Oxford University Press.

Komarovski, Y. (2008). Encountering ineffability — counting ineffability: on divergent verbalizations of the ineffable in 15th century Tibet. Acta Tibetica et Buddhica, 1, 1-15.

Komarovski, Y. (Forthcoming in 2011). Visions of Unity: The Golden Pandita Shakya Chokden's New Interpretation of Yogācāra and Madhyamaka. Albany, New York: State University of New York Press.

Lati Rinbochay, \& Hopkins, J. (1985). Death, Intermediate State and Rebirth in Tibetan Buddhism. Ithaca, NY: Snow Lion Publications.

Lati Rinbochay \& Denma Lochö Rinbochay (1983). Meditative States in Tibetan Buddhism. Boston: Wisdom Publications.

Longchen Rapjam (klong chen rab 'byams). (1994). Good Chariot: [Auto-]Commentary on the 'Illusion Revitalization of the Great Perfection' (Rdzogs pa chen po sgyu ma ngal gso'i 'grel ba shing rta bzang po). California: Yeshe De Project.

Longchen Rapjam (klong chen rab 'byams). (1994). Great Chariot: [Auto-]Commentary on the 'Mind Nature Revitalization of the Great Perfection' (Rdzogs pa chen po sems nyid ngal gso'i 'grel ba shing rta chen po). California: Yeshe De Project.

Lusthaus, D. (2002). Buddhist Phenomenology: A Philosophical Investigation of Yogācāra Buddhism and the Ch'eng Wei-shih Lun. London: RoutledgeCurzon.

Obermiller, E. (1936). Analysis of the Abhisamayālaṃkära. Calcutta Oriental Series, no. 27. London: Luzac $\&$ Co.

Obermiller, E. (1998). Prajñāpāramitā in Tibetan Buddhism. New Delhi: Paljor Publications.

Rongtön Sheja Künrik (rong ston shes bya kun rig). (1979). Lamp Clarifying the Five Paths: Quintessential Instructions on Incorporating into Experience the Essence of All Excellent Words-the Perfection of Wisdom (Gsung rab thams cad kyi snying po shes rab kyi pha rol tu phyin pa nyams su len pa'i man ngag/lam lnga gsal sgron). Gangtok, Sikkim: Sherab Gyaltsen.

Rongtön Sheja Künrik (rong ston shes bya kun rig). (1999). Moonrays of Essential Points: Abridged Essence of Incorporation into Experience (Nyams su len pa'i rim pa snying po mdor bsdus pa gnad kyi zla zer). The Collected Works of Rong-ston Shak-kya rgal-mtsen, vol. B (kha), 562-565. Dehra Dun, India: Sakya College.

Sakya Pendita Künga Gyeltsen (sa skya pandita kun dga' rgyal mtshan). (1989). Treasure of Valid Cognition: the Root Text and the [Auto-]Commmentary (Tshad ma rigs pa'i gter gyi rtsa ba dang 'grel pa). Bod ljongs mi dmangs dpe skrun khang.

Shakya Chokden (shākya mchog ldan). (1975). Appearance of the Sun Pleasing All Thinkers: Discussion of the History of the Chariot Ways of [Dignāga's] 'Sütra on Valid Cognition' and [its] Treatises (Tshad ma'i 
bstan bcos kyi shin rta'i srol rnams ji ltar 'byung ba'i tshul gtam du bya ba nyin mor byed pa'i snang bas dpyod ldan mtha' dag dga' bar byed pa). Collected Writings of Gser-mdog pan-chen Śäkya-mchog-ldan, vol. 19, 1-137. Thimphu, Bhutan: Kunzang Tobgey.

Shakya Chokden (shākya mchog ldan). (1975). Great Path of Ambrosia of Emptiness: Explanation of Profound Pacification Free from Proliferations (Zab zhi spros bral gyi bshad pa stong nyid bdud rtsi'i lam po che). Collected Writings of Gser-mdog pan-chenŚäkya-mchog-ldan, vol. 4, 107-207. Thimphu, Bhutan: Kunzang Tobgey.

Shakya Chokden (shākya mchog ldan). (1975). 'Hundred and Eight Dharma Sections' Treatise (Chos tshan brgya dang brgyad pa zhes bya ba'i bstan bcos). Collected Writings of Gser-mdog pan-chenŚákya-mchogldan, vol. 13, 159-462. Thimphu, Bhutan: Kunzang Tobgey.

Shakya Chokden (shākya mchog ldan). (1975). Precious Treasury of the Condensed Essence of the Profound and Extensive in Eight Dharma Sections (Zab rgya'i snying po bsdus pa rin chen gter mdzod chos tshan brgyad pa). In 'Hundred and Eight Dharma Sections' Treatise (Chos tshan brgya dang brgyad pa zhes bya ba'i bstan bcos). Collected Writings of Gser-mdog pan-chenŚäkya-mchog-ldan, vol. 13, 166-190. Thimphu, Bhutan: Kunzang Tobgey.

Shakya Chokden (shākya mchog ldan). (1975). Thorough Clarification of Definitive Meaning of the Five Doctrines of Maitreya (Byams chos lnga'i nges don rab tu gsal ba zhes bya ba'i bstan bcos). Collected Writings of Gser-mdog pan-chenśākya-mchog-ldan, vol.11, 1-37. Thimphu, Bhutan: Kunzang Tobgey.

Shakya Chokden (shākya mchog ldan). (1996). Rain of Ambrosia: Extensive [Auto-]Commentary on the 'Profound Thunder amidst the Clouds of the Ocean of Definitive Meaning' (Nges don rgya mtsho sprin gyi 'brug sgra zab mo'i rgyas 'grel bdud rtsi'i char 'bebs). In Two Controversial Mādhyamika Treatises, 319-499. Bir, India: Yashodhara Publications.

Sharf, R. H. (1995). Buddhist modernism and the rhetoric of meditative experience. Numen, 42(3), 228-283.

Short, L. (1995). Mysticism, mediation, and the non-linguistic. Journal of the American Academy of Religion, 63(4), 659-675.

Snodgrass, J. (2003). Presenting Japanese Buddhism to the West: Orientalism, Occidentalism, and the Columbian Exposition. Chapel Hill, North Carolina: The University of North Carolina Press.

Studstill, R. (2005). The Unity of Mystical Traditions: The Transformations of Consciousness in Tibetan and German Mysticism. Leiden: Brill.

Tenzin Gyatso, The Fourteenth Dalai Lama. (1987a). The Buddhism of Tibet. Ithaca: Snow Lion Publications.

Tenzin Gyatso, The Fourteenth Dalai Lama. (1987b). The Key to the Middle Way: A Treatise on the Realization of Emptiness. In T. Gyatso \& the Fourteenth Dalai Lama (Eds.), The Buddhism of Tibet. Ithaca: Snow Lion Publications.

Tenzin Gyatso, The Fourteenth Dalai Lama. (2009). Kindness, Clarity, and Insight. Snow Lion Publications, 2006.

Van Schaik, S. (2003). Approaching the Great Perfection: Simultaneous and Gradual Methods of Dzogchen Practice in the Longchen Nyingtig. Boston: Wisdom Publications, 2003.

Vasubandhu. (1998). Treasury of Higher Knowledge (Abhidharmakośakārikā). In Dwārikādās Śāstrī, Swāmī (ed.). The Abhidharmakośa \& Bhāṣya of Ācārya Vasubandhu with Sphutārthā Commentary of Ācārya Yaśomittrā. (2 vol.) Varanasi: Bauddha Bharati.

Vasubandhu. (2002). Thirty Stanzas (Trimśikākārikā). In Lusthaus, Dan. Buddhist Phenomenology: A Philosophical Investigation of Yogācāra Buddhism and the Ch'eng Wei-shih Lun. London: RoutledgeCurzon.

Walpola Rahula (1978). Zen and the Taming of the Bull: Towards the Definition of Buddhist Thought. London: Gordon Fraser.

Wedemeyer, C. K. (2007). Arryadeva's Lamp that Integrates the Practices (Caryāmelāpakapradīpa): The Gradual Path of Vajrayāna Buddhism According to the Esoteric Community Noble Tradition. New York: The American Institute of Buddhist Studies.

Williams, P. (1989). Mahāyāna Buddhism: The Doctrinal Foundations. New York: Routledge.

Yangchen Gawai Lodoe (1995). Paths and Grounds of Guhyasamaja. Dharamsala, India: Library of Tibetan Works and Archives.

Yao, Z. (2005). The Buddhist Theory of Self-Cognition. London: Routledge. 